\title{
VERBIDE TRANSITIIVSUSE KONTIINUMIST EESTI KEELES ${ }^{1}$
}

\author{
NATALIA VAISS
}

\begin{abstract}
Annotatsioon. Artikli eesmärk on kokku võtta ja täiendada senist teadmist eesti keele verbide transitiivsusest. Tuginedes varasematele uurimustele, käsitletakse verbide sihilisust kontiinumina ning pakutakse välja kuueastmeline skaala: 1) rangelt intransitiivsed verbid, mis ei esine sihitisega, 2) üldiselt intransitiivsed verbid, mis võivad esineda ebatüüpilise ja/või sisaldussihitisega, 3) prototüüpselt ja polüseemselt labiilsed verbid, 4) intransitiivsena kasutatavad transitiivsed verbid, mille puhul sihitiseta kasutus tõstab fookusesse verbiga väljendatud tegevuse, 5) üldiselt transitiivsed verbid, mis esinevad ka intransitiivsete kasutusmallidega, 6) rangelt transitiivsed verbid, mis üldjuhul ei võimalda objekti väljajättu. Verbide testimine eesti keele ühendkorpuse 2019. aasta versiooni materjalil kinnitab liigituse sobivust ning ilmestab iga rühma iseloomulikke jooni.
\end{abstract}

Võtmesõnad: verbisüntaks, argumentstruktuur, sihitis, polüseemia, korpuslingvistika

\section{Sissejuhatus}

Emakeeletunnist tuttav ülesanne jagada etteantud tegusõnad sihilisteks ehk transitiivseteks ja sihituteks ehk intransitiivseteks osutuks terve verbileksikoni korral ilmselt võimatuks missiooniks, kuna transitiivsus on skalaarne kategooria nii verbi kui lause tasandil (vt nt Lehrer 1970; Hopper, Thompson 1980; Dixon, Aikenvald 2000; Næss 2007). Peale rektsiooni varieerumise, nt usub seda, usub sellesse (Metslang 2017: 262), ning prototüüpselt labiilsete ehk ambitransitiivsete verbide (vt Kehayov, Vihman 2014), mida kasutatakse nii transitiivselt kui ka intransitiivselt, nt jalutab pargis, jalutab koera, leidub eesti keeles ka sihitisega esinevaid

1 Töö on valminud Haridus- ja Teadusministeeriumi Eesti Keele Instituudi baasfinantseerimise toel. Autor tänab anonüümseid retsensente edasiviivate kommentaaride eest. 
intransitiivseid verbe ja sihitiseta esinevaid transitiivseid verbe (vt nt Kont 1963; Tamm 2012). Nii laiendab mitmeid intransitiivseid verbe sisaldussihitis, nt magas sügavat und, elas oma elu, käis oma teed (Metslang 2017: 260-264), ja sekundaarne, ebatüüpiline sihitis, nt kukkus põlved katki, kukkus end surnuks, köhis end hingetuks, jooksis kingad puruks, magas kaela kangeks õla valusaks (Tamm 2012: 130-131; Erelt 2017b: 292, 2017e: 821). Implitsiitse sihitise ehk nullobjekti puhul eristatakse eesti keeles kahte transitiivset verbitüüpi: 1) obligatoorse sihitise laiendiga tegusõnad (lünk lauses on täidetav konteksti või situatsiooni põhjal), nt põhjustama: Kusjuures põhjustabki_väga sageli; 2) nii sihitisega kui ka ilma esinevad tegusõnad (objekti puudumisel on lause tähelepanu keskmes verbiga väljendatud tegevus), nt sööma: Sõin _ vaikselt köögis (Metslang 2017: 261).

Nagu näitavad korpuseotsingud ja teiste keelte põhjal tehtud uurimused (vt nt Lorenzetti 2008; Næss 2011), võib sihitiseta kasutus viidata ka tegusõna ühele konkreetsele tähendusele või regulaarsele kontekstile. Eesti keeles võib selle nähtuse tõestuseks tuua järgmised näited: Ta enam ei joo; Ta ei näe prillideta hästi; Ammu pole näinud; Firma jätkab turu liidrina; Direktor jätkab oma ametis. Polüseemsete verbide puhul on samuti võimalikud nii transitiivne kui ka intransitiivne kasutus (Luraghi 2004: 236), nt eesti tegusõna pü̈̈dma kohta leiab eesti keele ühendkorpusest mõlema kasutusmalli näiteid: pü̈̈ab palli, püüab kala, püüab õigel ajal tulla (transitiivne); püüab kõigest väest, püüab päikese poole (intransitiivne).

Võttes kokku ülalmainitud uurimistulemused ja arvestades eesti keele ühendkorpuse materjalil tehtud tähelepanekuid, sõnastan järgmise uurimisküsimuse: kas eesti keele verbide transitiivsust saaks kirjeldada järjepideva skaala ehk kontiinumina, eristades kuut põhilist verbitüüpi: 1) rangelt intransitiivsed verbid, mis ei esine sihitisega; 2) üldiselt intransitiivsed verbid, mis võivad esineda ebatüüpilise ja/või sisaldussihitisega; 3 ) prototüüpselt ja polüseemselt labiilsed verbid; 4) intransitiivsena kasutatavad transitiivsed verbid, mille puhul sihitiseta esinemine tõstab fookusesse verbiga väljendatud tegevuse; 5) üldiselt transitiivsed verbid, millel on paralleelne, muu kui sihitise rektsioon ja/või regulaarseks muutunud sihitiseta alltähendused või kasutusmallid; 6) rangelt transitiivsed verbid, mis üldjuhul ei võimalda objekti väljajättu. Varasematele uurimustele tuginedes valisin igasse rühma viis verbi ning kontrollisin nende transitiivsuse määra 
eesti keele ühendkorpuse 2019 (ENC19)² materjalil (vt lähemalt osast 3). Korpuse põhjal tehtud analüüs on ennekõike kvalitatiivne, ehkki kasutan materjalis ilmnevate tendentside jälgimiseks ka arvandmeid.

\section{Transitiivsus, verbivalents, labiilsus}

Keeleuniversaaliks peetav transitiivsus ehk sihilisus on kompleksne keelenähtus, mis ühendab endas süntaksit ja semantikat. Prototüüpselt transitiivsed olukorrad väljendavad energia ülekandmist kahe osaleja vahel, mida intransitiivses olukorras ei toimu. Prototüüpne objekt on seega tavaliselt patsiendi rollis ja prototüüpne subjekt agendi rollis. (Vt põhjalikumalt Næss 2007.)

Süntaksi tasandil on transitiivsus tihedalt seotud verbivalentsiga, mis määrab, mitut obligatoorset laiendit (transitiivsuse seisukohalt mitut argumenti) tegusõna üldjuhul tingib. Transitiivsed verbid on vähemalt kahevalentsed, nõudes enamasti kahte argumenti: subjekti ja objekti, lisaks võib mõnel tegusõnal olla teisigi obligatoorseid laiendeid, nt lauses Peeter kammis juukseid on verb kammima kahevalentne, lauses Peeter rääkis vennale uudise on verb rääkima kolmevalentne (Rätsep 1978: 242). Intransitiivsed verbid on harilikult ühevalentsed (nõuavad ühte argumenti: subjekti), nt Tund lõppes. Samas leidub ka hulgaliselt ambivalentse käitumisega verbe (vt põhjalikumalt Næss 2007: 123-124), vrd nt nullvalentne Külmetas (Rätsep 1978), ühevalentne Käed külmetavad ja kahevalentne Pehme käepide ei külmeta käsi (ENC19).

Kõige tuntum transitiivsuse semantilis-süntaktiline käsitlus on Hopperi ja Thompsoni skaala (1980), mille järgi seostuvad n-ö suurema transitiivsusega järgmised tunnused: 1) lauses on kaks või rohkem osalejat (agent ja objekt), 2) lause väljendab aktiivset tegevust, 3) tegevus on teeline (perfektiivne aspekt), 4) tegevus on punktuaalne, 5) tegevus on tahtlik, 6) lause on jaatav, 7) predikaat on kindla kõneviisi vormis, 8) lause subjekt on suure agentiivsusega, 9) lause objekt on täielikult tegevusega hõlmatud, 10) lause objekt on „kõrgelt individualiseeritud“. Mida rohkem loetletud kriteeriume lausel on, seda suurem on selle semantiline transitiivsus. Toetudes esitatud skaalale, seletatakse muu hulgas ka implitsiitse objekti

2 Eesti keele ühendkorpus 2019 on praegu kõige suurem eesti keele korpus, mille maht on 1,5 miljardit sõna. Korpus koosneb kaheksast allkorpusest ja sisaldab eri tüüpi tekste (https://app.sketchengine.eu/, 01.02.2021). 
võimalikkust mõne verbi juures (Næss 2007: 134-138), mida vaatlen põhjalikumalt allpool.

Kasutuse põhjal jaotuvad enamiku keelte verbid kolme süntaktilisse põhitüüpi: 1) sihitu ehk intransitiivne - ei esine sihitisega, nt jääma, 2) sihiline ehk transitiivne - üldjuhul esineb sihitisega, nt jätma, 3) labiilne ehk ambitransitiivne - verbi kasutatakse nii intransitiivselt kui ka transitiivselt, nt kolib teise korterisse, kolib klaverit teise korterisse. Keeliti leidub ka alltüüpe. (Vt Dixon, Aikhenwald 2000: 12-13.)

Eesti keele puhul on täheldatud, et osa üldjuhul intransitiivseid verbe saab esineda sisaldussihitise ja ebatüüpilise objektiga, nt jookseb spurti, jooksis end hingetuks, jooksis selja higiseks (vt nt Kont 1963; Tamm 2012; Metslang 2017). Sisaldussihitis on figura etymologica üks ilminguid ning seda peetakse keeleuniversaaliks. Ühelt poolt on sisaldussihitis, mis väljendab sama või sünonüümset tegevust kui põhisõnaks olev verb, semantilises mõttes tühi (Kulikov 1999). Teiselt poolt peab igal keelenähtusel olema mingi eriline funktsioon, milleks peetakse sisaldussihitise puhul tegevusele piiritletuse lisamist (Horita 1996; Kitahara 2010: 38). Nii on sisaldussihitisega lause Ta tantsis tantsu piiritletum kui Ta tantsis hästi. Samuti on pandud tähele (vt Horita 1996), et sisaldusobjekt esineb lauses üldjuhul täiendiga (nt elas õnnelikku elu, elas oma elu) ning üsna harva ilma - tavaliselt kas poeetilises keelekasutuses või teatud verbide puhul (nt tantsis tantsu, laulis laulu). Täiendiga sisaldusobjekt konkretiseerib tegevust (ingl type of activity), kuid selle asemel võib verbi laiendada sünonüümse tähendusega määrus. Kahe sõnastusvõimaluse vaheks peetakse aga seda, et objekti olemasolu lisab tegevusele aspektuaalset piiritletust. (Ibid.) Nii tähistab fraas elas õnnelikku elu semantiliselt piiritletumat tegevust kui sarnase sisuga elas õnnelikult.

Vaatamata sellele, et eesti keeles on sisaldussihitis üsnagi regulaarne nähtus, mis võib laiendada paljusid intransitiivseid ja transitiivseid verbe, peetakse seda perifeerseks sihitiseliigiks. Sihitule tegusõnale lisatav sisaldusobjekt võib täpsustada verbi tähendust, väljendades näiteks tegevuskohta (käisime seda teed) või viisi (magas rahulikku und). Sisaldussihitise eriliigiks on mõnede tugiverbiühendite laiemalt varieeruva sõnastusega sihitised (sõitis rallit, hüppas kolmikut). (Metslang 2017: 260, 263-264) Ehkki inglise keele uurijate seas ei ole üksmeelt, kas sisaldussihitis on verbi argument või vaba laiend (vt põhjalikumalt Kitahara 2010), tundub eesti keele sisaldussihitis täisõigusliku sihitiseliigina, kuna nagu sihitiselegi 
omane võib see olla leksikaliseerunud, nt magab talveund, ujub liblikat, või eristada aspekti, võimaldades käändevaheldust, nt jooksis eile kevadist poolmaratoni $\sim$ kevadise poolmaratoni.

Inglise keeles eristatakse intransitiivverbide kahte klassi: 1) mitteergatiivsed (ingl unergative), mille puhul on subjekt agendi või kogeja rollis, nt ta naeratab või tantsib ning ta magab või köhib, 2) mitteakusatiivsed (ingl unaccusative), mille puhul on subjekt patsiendi rollis, nt film algab, küünal põleb. Esimesed saavad esineda sihitisega ja moodustada passiivi, teised mitte. Samas ei ole piirid alati selged. (Vt põhjalikumalt Kitahara 2010; Torn 2002.) Eesti keeles eristuvad: 1) sisaldussihitist ja ebatüüpilist, sekundaarset objekti võimaldavad verbid, nt magama, jooksma, köhima, kukkuma (vt Tamm 2012: 127-131; Metslang 2017: 263-264; Erelt 2017b: 292), ja 2) neid mittevõimaldavad verbid, nt jääma, algama, sõltuma, kuid inglise keele intransitiivsete verbitüüpidega ei pruugi need klassid ühtida. Samas tundub, et agentiivsus ehk seostumine elusa subjektiga on ka eesti keeles ebatüüpilise objekti ja sisaldussihitise esinemist soodustav tegur (vt Tamm 2012). Ebatüüpilise objekti kasutuse puhul on huvitav märkida, et see võimaldab ökonoomsemalt väljenduda (vrd nt Ta kärkis kurgu kähedaks ja Ta kärkis nii, et kurk jäi kähedaks).

Sisaldussihitis ja ebatüüpiline objekt on vaid kaks sihitiseliiki, mis on keeles üsnagi regulaarsed, kuid jäävad oma leksikaalse piiratuse poolest ikkagi perifeeriasse. Sihitisena esineb eesti keeles tavaliselt: 1) verbist sõltuv osastavaline, omastavaline või nimetavaline substantiivifraas, ka adjektiivi- või kvantorifraas, nt Aednik kasvatas suure kõrvitsa; Ta ootas mind seda; Saatus soosib julgeid; Mitu inimest saadeti metsa istutama; 2) da-infinitiivifraas, nt Nad armastavad hommikuti kaua magada;3) vattarind, nt Arvasin tal piinlik olevat; 4) osalause, nt Ta teadis, et Juhan on haige; 5) kvaasisubstantiivne keelend, nt Üks kirjutab „,Afrika“, teine jälle „Aafrika“ (Metslang 2017: 258).

Sihitisega sarnanevad vormivahelduse poolest kestus-, korduvus- ja kvantumimääraadverbiaalid (nt magas terve öö, ütles sada korda, kaalub mitmeid tonne, jooksis kaks kilomeetrit, kõndis tükk maad) ehk osmad (Metslang 2008: 109). On täheldatud, et mõned juhtumid paiknevad sihitise ja määruse piiril, nt ühendi sadat meetrit jooksma puhul võib hulgaväljend tähistada nii spordialale omast määra kui ka kogust üleüldse. Partitiivis (nt Jüri jooksis sadat meetrit) väljendavad need spordiala, olles spetsiifiliste tugiverbiühendite sihitised. Totaalsel kujul (nt Jüri jooksis sada meetrit) 
on võimalikud mõlemad tõlgendused: sihitis küsimusega mis $\sim$ mille? ja määrus küsimusega kui palju?. Kui lauses on piiri andev abimäärsõna või määrus (nt Jüri jooksis sada meetrit ära), tähistab hulgaväljend pigem alale omast määra ja vastab küsimusele mille? (Metslang 2017: 276, vt ka Metslang 2008: 132-134).

Sihitis võib olla lauses ka eksplitsiitselt väljendamata, elliptiline objekt on eesti keeles üsnagi tavaline (Kehayov, Vihman 2014: 1067; Erelt 2017c: 597-598). Eristatakse kahte tüüpi objekti väljajättu võimaldavaid verbe (Metslang 2017: 261):

1) verbid, mille puhul on sihitis obligatoorne laiend (nt põhjustama, omama, sisaldama), sihitise puudumisel on lünk lauses täidetav konteksti või situatsiooni põhjal ning selline ellips ei muuda lauset intransitiivseks, kuna semantiliselt on konkreetne objekt olemas, nt Omavad_ikka küll;

2) nii sihitisega kui ilma kasutatavad verbid (nt sööma, õmblema, koristama, pesema), sihitise puudumisel on siin lause tähelepanu keskmes verbiga väljendatud tegevus ning vormistamata sihitis võib tähendada mis tahes mõeldavat referenti üldiselt või viidata kontekstisidusalt teadaolevale referendile, nt Me hakkasime töölepesime _, kü̈̈risime _, puhastasime _, rääkisime, kuidas õhtul kuuske hakkame kaunistama.

Objekti väljajättu nimetatakse nullobjektiks ${ }^{3}$ ning eristatakse definiitset ehk kontekstist sõltuvat (ingl definite object deletion, DOD) ${ }^{4}$ ja indefiniitset ehk kontekstist sõltumatut, geneerilist nullsihitist (ingl indefinite object deletion, IOD). Esimese puhul saab objekti referendi leida kas lause enda või eelneva konteksti põhjal, teise puhul võib väljajäetud objekt tähendada mis tahes mõeldavat referenti ning sageli pole objekti referendi tähistamine üldsegi oluline, nt Ta sööb_ praegu. Kontekstist olenevalt võimaldavad definiitset nullobjekti ilmselt kõik transitiivsed verbid, indefiniitset aga üldjuhul teatud rühmade verbid. Geneerilise nullobjektiga esinevad paljudes keeltes 1) verbid, mille puhul on tegevusega või selle tulemusena mõjutatud peale objekti ka subjekti referent (ingl affected-agent verbs), nt sööma, jooma, õppima, lugema, ning 2) objekti loomist eeldavad verbid

3 Edaspidi tähistan sünonüümsete terminitega nullobjekt $\sim$ nullsihitis ja implitsiitne objekt implitsiitne sihitis iga keelelist konteksti, kus objekt on semantiliselt olemas või on põhimõtteliselt võimalik, kuid eksplitsiitselt väljendamata.

4 Eesti grammatikatraditsioonis kuulub definiitne nullobjekt kontekstiellipsi alla. 
(ingl effected-object verbs), mille puhul tekib objekt verbiga väljendatud tegevuse tulemusel, nt joonistama, küpsetama (pirukaid). Sageli võimaldavad indefiniitset nullobjekti ka koristama-tüüpi verbid ning mõnes keeles tajuverbid. Samas võib leiduda ka kontekste, kus geneerilist nullobjekti võimaldab obligatoorse sihitisrektsiooniga tegusõna. (Vt Næss 2007: 124-131.)

Objektiga esinemise alusel saab verbe liigitada mitmeti. Ühe huvitava jaotuse pakub Adrienne Lehrer (1970), jagades verbid nelja klassi:

1) „spetsiifilise sihitisega“" verbid - nende verbide puhul on teada, mis tähendustüüpi sihitised on üldjuhul võimalikud, nt sööma korral on objekti rollis tavaliselt mingi toit ning teist tüüpi sihitis ei ole antud juhul tüüpiline; siia rühma kuuluvad samuti küpsetama, jooma, kuulama, triikima, nuusutama ning tihti ka sisaldussihitisega esinevad verbid, nt unistama (oma unistust), hingama (värsket ôhku), tantsima (mingit tantsu);

2) „mitme sihitise võimalusega“ verbid - polüseemsed verbid, mille eri tähendustüüpidega kaasnevad erilaadsed, hästi ennustatavad sihitised, nt eesti keeles võib öelda peseb end hambaid aknaid $\sim$ nõusid last vms; parandab vigu elektroonikat, küsib nõu abi küsimusi; kui kontekst toetab lausest arusaamist, võib objekti välja jätta, ilma et sisu kannataks, nt kui subjekti rollis on muusik või jalgpallur, on fraasi mängibki väga hästi puhul nullobjekti rollis mingi muusikariist või jalgpall;

3) kontekstiellipsit võimaldavad verbid - väljajäetud sihitise rollis on sageli määratlevad või isikulised asesõnad seda, teda, neid jms, nt Ära tee [seda]!;

4) geneerilist konteksti võimaldavad verbid - väljajäetud sihitisena saaks tavaliselt lisada sõnu midagi, kedagi või mitte midagi, mitte kedagi vms, nagu lauses Ta ei varastaks kunagi.

Lehreri hinnangul (1970) ei ole piirid nimetatud klasside vahel ranged, kuna leidub verbe, mis kuuluvad korraga mitmesse kategooriasse. Samas näitab teooria, millised nullobjektid on võimalikud.

Lause tasandil tingivad nullobjekti korduvad ja habituaalsed tegevused (nt Tiigrid jahivad öösiti; Sarimõrvar on jälle tapnud) ning kasutusjuhud, mille puhul on tegevus fookusesse tõstetud, sageli muude lauseelementide toel (nt Kokaabi lõikas ja tükeldas terve hommikupooliku; Ta luges oma autos; See koer ei hammusta) (vt Goldberg 2001). Samuti soodustavad 
implitsiitset sihitist mitmed süntaktilised mallid, nt imperatiiv, eriti toiduretseptides ja juhistes (nt Lõika kuubikuteks!; Peske hoolikalt maha), ning kahe või enama tegevuse samaaegsust, järjestatust või vastandamist väljendavad konstruktsioonid (nt Süües ei tohi rääkida; Ta pesi, triikis, koristas, tegi süüa; Mari koristas, aga Mart luges; Võtta või jätta?) (vt Velasco, Muñoz 2002; Lorenzetti 2008; Onozuka 2007). Nagu ka mõne teise keele puhul (vt nt Luraghi 2004) on eesti keelele omane keele ökonoomsuse printsiibist tulenev nullobjekt, mis esineb sama sihitist omavate kahe või enama tegusõna korral, nt ta pesi_ja kuivatas nõusid, samuti reduplikatiivse rinnastuse (nt ootab ja ootab) ning rindverbide konstruktsioonide korral, kus väljendatud tegevused on justkui sulandunud üheks, nt sõime ja jõime (vt Erelt 2017d: 610). Seda tüüpi nullsihitist võib eesti keeles nimetada loomulikuks nullobjektiks.

Nullobjekt ei vähenda mitte ainult lause transitiivsust, vaid ka aspektuaalset piiritletust: ta sööb lõunat on sooritus (ingl accomplishment) ning ta sööb oma toas on tegevus (ingl activity) (vt Næss 2007: 133-135). Ellipsit soodustab ka objekti eeldatavus. Mida spetsiifilisem ja idiomaatilisem on sihitis, seda tõenäolisemalt jääb see eksplitsiitseks (vt Velasco, Muñoz 2002). Nii otsime väljajäetud objekti tavaliselt tüüpilisemast kontekstist, nt lause Koristasin_täna hommikul puhul eeldame, et väljajäetud objektiks on kodu, mitte näiteks prügi, viljad või hein. Samas võib nullobjekt viidata ka tegusõna ühele konkreetsele tähendusele või regulaarsele kasutusele, nt jooma puhul jäetakse objekt sageli välja tähenduses 'alkoholi tarbima' ning nägema puhul on võimalik modaalne tähendus ja hulk kinnistunud väljendeid (Ta ei näe prillideta hästi; Ammu pole näinud vms) (vt Næss 2007, 2011; Lorenzetti 2008). Mõne tegusõna puhul on nullobjektiga kasutus justkui muutunud leksikaalselt kinnistunud kontekstiks (nagu mittehammustava koera näites).

Nullobjekti puhul on kasutus vormilt intransitiivne, kuid semantiliselt transitiivne. Transitiivsuse mõttes on erilised ka erinevad passiivi-ilmingud (Keenan, Dryer 2007; Neshcheret 2016: 14). Eesti keeles on peale implitsiitse objekti semantiliselt, kuid mitte süntaktiliselt transitiivsed ka 1) passiivilaused, nt Remont on alustatud; Hinnad on kodulehel näha; 2) mata-, tud- ja tav-tarindid atribuudi ning $d a$-infinitiiv adverbiaali funktsioonis, nt seni nägemata paigas, alustatud kriminaalmenetlus, söödav seen, toit kõlbab süüa; 3) leksikaliseerunud des- ja mata-tarindid, nt sõprade nähes, kellegi nägemata (vt Torn 2002; Erelt 2017a: 218-230, 2017e: 813-814). 
Intransitiivseid verbe laiendavat ebatüüpilist ja sisaldussihitist ning ilma objektita kasutatavaid transitiivseid verbe, nagu ka rektsiooni varieeruvust (nt usub seda usub sellesse), ei peeta tavaliselt prototüüpse labiilsuse ilminguteks, vaid sellega sarnanevateks nähtusteks (vt nt Letuchiy 2013). Verbide labiilsust uurinud Petar Kehayov ja Virve-Anneli Vihman (2014) on tuvastanud eesti keeles üle 90 labiilse verbi, toetudes Alexander Letuchiy (2006a) prototüüpselt labiilse verbi kriteeriumitele: 1) verbi kasutatakse transitiivselt ja intransitiivselt; 2) subjekti omadused või muud situatsiooni semantilised omadused erinevad transitiivses ja intransitiivses kasutuses märkimisväärselt, nt laps pahandab ema - ema pahandab; 3 ) tegemist ei ole väljajäetud objektiga, nt Jüri sööb lõunat Jüri sööb_; 4) tegemist ei ole homonüümiaga, nt nokib teri-nupp nokib. Vene keeles on labiilseid verbe 30 ringis (Letuchiy 2006b). Inglise keeles on väidetavalt üle 800 labiilse verbi (McMillion 2006).

Eesti keeles on esindatud kõik neli labiilsuse põhitüüpi (Kehayov, Vihman 2014):

1) patsienti säilitav ehk P-labiilsus (transitiivses ja intransitiivses kasutuses on sama patsient), nt poiss pritsib vett-vesi pritsib; siia kuuluvad emotsiooniverbid rõõmustama, ehmatama, pahandama, kurvastama, imestama, jahmatama, kohmetama jt, faasiverbid peatama ja seisatama, deskriptiivsed ja onomatopoeetilised verbid krussima, prantsatama, lirtsama, lirtsatama, aga ka muu semantikaga verbid, nt mängima, külmetama, hullutama, kleepima, passima; eesti keeles on vähemalt 54 sellist verbi;

2) agenti säilitav ehk A-labiilsus, nt kolis teise linna - kolis sõbra teise linna; siia kuuluvad ka jalutama, kiirustama, sõitma, ulatama; kokku vähemalt 19 verbi;

3) refleksiivne labiilsus, nt pööras lehte - pööras vasakule, sirutas käsi - sirutas ja tõusis; kokku vähemalt 12 verbi;

4) retsiprookne labiilsus, nt Jüri suudles Marit - Jüri ja Mari suudlesid; samuti kallistama, embama, kokku vähemalt 8 verbi.

Suur osa eesti keele labiilsetest verbidest on sufiksite -ta-, -sta-, $-n d a-,-r d a-$ ja -tle- abil saadud tuletised. Labiilsuse tuuma moodustavad emotsiooniverbid, deskriptiivsed ja onomatopoeetilised verbid. Teise semantikaga labiilsete verbide rühmad jäävad perifeeriasse. Suhteliselt ulatusliku labiilsuse põhjusteks eesti keeles võivad olla: 1) intensiivne kontakt saksa keelega, mis on rikas labiilsete verbide poolest; 2) labiilsuse 
kasutamine kompensatsioonimehhanismina valentsi vähendamiseks; 3) erinevate derivatsioonisufiksite foneetiline kokkulangemine, mis põhjustab tuletiste valentsuse mustrite valet tõlgendamist; 4) vormil põhinev analoogia, nn klasterlabiilsus, nt lirtsama > lirtsatama. Lisaks kujutavad labiilsed verbid endast avatud klassi, neid tekib aja jooksul keelde juurde, nt Ma login välja - Ma login sind välja. (Kehayov, Vihman 2014)

Paljudes keeltes on liikumis- ja faasiverbid prototüüpselt labiilsed või labiilsusele kalduvad (Letuchiy 2013). Viimane tundub paika pidavat ka eesti keele puhul. Korpuseotsingud näitavad, et paljud liikumisverbid võimaldavad sisaldussihitist (käib oma teed, kõnnib oma rada, astub sammu jms) ning mõned transitiivsed faasiverbid esinevad tihti nullobjektiga justkui kinnistunud kontekstides, nt jätkab oma ametis, võib lõpetada halvasti. Polüseemsete verbide puhul on samuti sageli võimalik nii transitiivne kui intransitiivne kasutus. Nii esineb P-labiilsust võimaldav tegusõna mängima ka muudes transitiivsetes ja intransitiivsetes kontekstides (vt rohkem osast 4.3).

Eelnevast lähtudes on näha, et verbide jaotus transitiivsuse alusel ei piirdu eesti keeles üksnes verbide jagunemisega sihilisteks, sihituteks ja prototüüpselt labiilseteks, vaid ühendab endas palju teisigi nähtusi, nagu näiteks ebatüüpiline ja sisaldusobjekt, nullobjekt, leksikaliseerunud kasutusjuhud, alternatiivsed rektsioonid ja ambitransitiivse kasutusega polüseemsed verbid.

\section{Transitiivsuse skaala testimise põhimõtted}

Tuginedes eelmises osas tutvustatud teooriataustale, otsin järgnevalt vastust küsimusele, kas eesti keele verbide transitiivsust võib vaadelda kuueastmelise kontiinumina: 1) rangelt intransitiivsed verbid, 2) üldiselt intransitiivsed verbid, 3) prototüüpselt ja polüseemselt labiilsed verbid, 4) intransitiivsena kasutatavad transitiivsed verbid, 5) üldiselt transitiivsed verbid, 6) rangelt transitiivsed verbid (vt rühmade täpsemat kirjeldust osast 1). Valisin seniste käsitluste põhjal igasse rühma viis verbi, mis kuuluvad ühtlasi eesti keele põhisõnavara hulka (vt Kallas jt 2015): 1) sulama, tutvuma, loobuma, nõustuma, ühinema (Tamm 2012), 2) kukkuma, magama, jooksma, laulma, tantsima (Horita 1996; Tamm 2012; Erelt 2017b; Metslang 2017), 3) rõõmustama, jalutama, pöörama, suudlema, mängima (Kehayov, Vihman 2014), 4) sööma, harjutama, 
koristama, kirjutama, õmblema (Metslang 2017), 5) alustama, jätkama, lõpetama, jooma, nägema (Lorenzetti 2008; Næss 2011; Letuchiy 2013), 6) moodustama, põhjustama, sisaldama, eeldama, omama (Metslang 2017).

Verbide sobivust ühte või teise rühma testisin leksikograafilise tarkvara Sketch Engine abil eesti keele ühendkorpuse 2019 (ENC19) materjalil. Iga näiteverbi kohta analüüsisin 500 juhuslikult valitud korpuselauset, kasutades funktsioone „Concordance“ (konkordants), mis võimaldab näha korpuselauseid, kus otsitav sõna esineb eri grammatilistes vormides, ja „Shuffle“ (konkordantsid eri allkorpustest juhuslikus järjekorras), et valikus oleks korpuselauseid kõigist allkorpustest. Lisaks vaatasin funktsiooni „Word Sketch“ abil analüüsitavate verbide sõnavisandeid, et näha otsitava sõna sagedasemaid kollokatsioone (vt Kilgarriff jt 2014), ja vajadusel tegin korpusest konkordantsi lisaotsinguid. Analüüsi eesmärk oli ennekõike kvalitatiivne: fikseerida süntaktiliselt transitiivsed (eksplitsiitne objekt), semantiliselt transitiivsed (nullobjekt ja osas 2 kirjeldatud juhtumid) ning intransitiivsed kasutusjuhud ja analüüsida, mis kontekstides need esinevad. Lisaks olen toonud välja ka uurimisteema seisukohalt olulisi arvandmeid materjalis ilmnevate kasutustendentside jälgimiseks.

Keelematerjali täpsemaks kirjeldamiseks olen iga verbi juures näidanud nende lausete arvu, mis ei ole pooliku või ebaselge grammatilise ${ }^{5}$ struktuuri või teise tähenduse tõttu ${ }^{6}$ analüüsiks sobinud. Paljudel juhtudel esines materjalis ka analüütilisi verbe, nt verbi nägema konkordantside puhul ette nägema, läbi nägema jms. Kui analüütilisi tegusõnu oli palju või nende kasutus oli transitiivsuse väljendamise seisukohalt tähtis, mainin seda tulemuste kirjeldamisel. Vajadusel olen üles märkinud muude uuritava teemaga seotud kasutusjuhtude arvu.

${ }^{5}$ Lausete ebagrammatilisust olen kontrollinud kahe emakeelekõneleja peal. Juhul, kui lauses oli trükivigu, puudusid kirjavahemärgid vms, kuid lause oli arusaadav (sh ümbritseva keelekonteksti põhjal), ei pidanud ma seda ebagrammatiliseks.

${ }^{6}$ Mõne tegusõna korral sattus konkordantsi otsinguga materjali hulka ka teise tähendusega sõnu - vormilisi või leksikaalseid homonüüme. Näiteks verbi sulama vormideks oli märgendatud 49 korral kas nimisõna sula ühes kahest tähendusest ('talvine ilmastikunähtus' või 'sularaha'), omadussõna sula või verbi sulatama konditsionaal; kuuel korral oli tegusõna jooma vormiks loetud verbi jooksma lihtminevik või substantiivi joom vorm ning kaheksal korral oli verbi omama vormiks loetud adjektiiv oma, tavaliselt inessiivis. Kahel korral oli tegusõna kukkuma konkordantsides käo häälitsemist tähistav verb. 
Kõik allpool esitatud näited pärinevad 2019. aasta eesti keele ühendkorpusest (ENC19), poolpaksu kirjaga olen esile tõstnud näidete olulisi osi.

\section{Verbide testimise tulemused}

\subsection{Rangelt intransitiivsed verbid}

Selles rühmas on testitud järgmisi tegusõnu: sulama, tutvuma, loobuma, nõustuma ja ühinema, mida on maininud Anne Tamm (2012) kui verbe, mis ei võimalda sisaldussihitist ega ebatüüpilist objekti. Korpusematerjali analüüs kinnitab, et antud verbid tõepoolest ei esine koos ebatüüpilise ega sisaldussihitisega.

Sulama on ühevalentne verb, mis ei nõua peale aluse teisi obligatoorseid laiendeid. Verbil on derivatiivselt markeeritud kausatiivse tähendusega transitiivne paariline sulatama. Tegusõna kollokatiivseks subjektiks on üldjuhul sulada võiv aine (nt jää, lumi, juust, jäätis), lisaks juhtme isolatsioon, aknad vms, kujundlikus kasutuses maitsev toit (mis lausa sulab suus), süda, piir, hinnaerinevus, vahe, edu vms (kaks viimast eriti spordis, nt (1), (2)). Kõik mainitud subjektid on mitteagentiivsed.

(1) Kaitsemäng sai värskust juurde ja vahe hakkas sulama.

(2) Algedu sulas küll korra 17:16-le, siis alustasid eestlased spurti.

Lisaks lihtverbile sulama esines materjalis lauseid analüütiliste verbidega, nt ära sulama, üles sulama, kokku sulama, kinni sulama, ühte sulama, millel on tavaliselt aspekti seisukohalt perfektiivne tähendus. Sama funktsiooni täidab sulama puhul ka translatiivne või illatiivne laiend, nt jäätis sulab vahuks pehmeks, kõrvalhooned sulavad nüüdisaegsesse hoonestusse.

Tegusõnad tutvuma, loobuma ja nõustuma on üldjuhul kahevalentsed. Tutvuma nõuab komitatiivset laiendit, nõustuma kas komitatiivset või mainfinitiivi laiendit, loobuma elatiivset või mast-tarindi kujulist laiendit. Samas esinevad need verbid ka ilma määruslike laienditeta (vt tabel 1) ning määruste väljajätu kontekstid on samasugused kui nullobjekti korral, mida vaatlen lähemalt osades 4.3-4.6. 
Tabel 1. Verbide sulama, tutvuma, loobuma, nõustuma ja ühinema kasutamine ilma obligatoorsete määrusteta 500 korpuselauses

\begin{tabular}{|l|c|c|}
\hline Tegusõna & $\begin{array}{c}\text { Obligatoorsete määrusteta } \\
\text { kasutusjuhtude arv }\end{array}$ & $\begin{array}{c}\text { Analüüsiks mittesobivate } \\
\text { lausete arv }\end{array}$ \\
\hline sulama & - & 52 \\
\hline tutvuma & 23 & 3 \\
\hline loobuma & 38 & 4 \\
\hline nõustuma & 97 & 6 \\
\hline ühinema & 112 & 0 \\
\hline
\end{tabular}

Tutvuma ja loobuma puhul sarnanes enamik obligatoorse määruseta kasutusjuhte definiitse nullobjektiga $(3,4)$. Kõige sagedamini esines seda tüüpi ellips infinitiivkonstruktsioonides (nt tuli naabri juurde tutvuma, on teavitanud enda soovist loobuda) ja imperatiivi puhul (3). Harvadel juhtudel oli kontekst sarnane pigem indefiniitse nullobjektiga $(5,6)$. Tutvuma esines komitatiivse laiendita ka mitmusliku subjekti puhul (nt lõpuks nad tutvusid), sh koos aja- ja/või kohamäärusega, ning viisakusväljendi rõõmustav tutvuda koosseisus.

(3) Katastritunnus: 34801:005:0045 Tule ja tutvu _!

(4) Neiu ei loobunud , täitis taas kandideerimisankeedi, kordus sama.

(5) Praegu Inglismaal igavlev kena brünett neiu soovib tutvuda _.

(6) Tumesinine viitab ka kohanemisele olemasolevate võimalustega, valmisolekule anda ja loobuda _, tagasihoidlikkusele.

Nõustuma puhul esines komitatiivse laiendi väljajättu 53 korral enne kõrvallauset (7) ning 11 korral oli tegemist otsekõnega (8), 31 korral muu definiitse (9) ja 2 korral indefiniitse obligatoorse määruse väljajätuga (10).

(7) Seega te nõustute _, et tänases Eestis on parem kui varem?

(8) „Peab olema,“ " nõustus_ Grant.

(9) Ma nõustusin _ vastumeelselt.

(10) Kuulata ja öelda, vaielda ja nõustuda _ või mitte nõustuda _on ikka kõige parem oma emakeeles.

Tegusõna ühinema kasutatakse sageli komitatiivse, translatiivse või illatiivse laiendiga. Obligatoorsete määrusteta esines ühinema analüüsitud materjalis 22 korral definiitse nullmäärusega (11) ning 90 korral tähenduses 'omavahel ühinema' (12), sh koos laienditega kelle vastu või mille ümber, 
mida saab lugeda leksikaliseerunud kasutuseks, kust on laiend 'omavahel' või 'üksteisega' välja jäetud.

(11) Ehk ühineb_keegi veel, seltsis segasem.

(12) Kõik blogivanaemad, ühinege!

Tegusõnadel tutvuma ja ühinema on derivatiivselt markeeritud kausatiivse tähendusega transitiivsed paarilised (tutvustama, ühendama). Verbidel loobuma ja nõustuma on transitiivsed tuletised loovutama ja nõustama, mis ei ole regulaarsed tähenduslikud paarilised. Tutvuma, loobuma ja nõustuma subjektid on harilikult agendi rollis, ühinema puhul on võimalik nii agentiivne kui mitteagentiivne subjekt (nt seitse haiglat on ühinemas).

Semantiliselt tundub vaatlusalune verbirühm väga heterogeenne (vt põhjalikumalt Tamm 2012). Süntaktilisest vaatenurgast lähtudes võib aga kindlalt öelda, et siia rühma kuuluvad verbid, millel on muu kui otsesihitise rektsioon, nt loobuma, tutvuma, nõustuma, ühinema. Hopperi ja Thompsoni (1980) skaala järgi võivad subjekti omaduste poolest ühed laused olla suurema transitiivsusega kui teised. Nii on subjekti agentiivsust arvestades verbil sulama väiksem semantiline transitiivsus kui tegusõnadel nõustuma, tutvuma, loobuma ja ühinema. Kuna verbi obligatoorse laiendina esinevad määrused sarnanevad sisuliselt objektiga, on neid nimetatud kas kaudsihitiseks või sihitismääruseks (vt põhjalikumalt Veismann jt 2017: 306-307). Nii võiks põhimõtteliselt vaadelda obligatoorse määrusega intransitiivseid tegusõnu kui mõnevõrra suurema semantilise transitiivsusega verbe võrreldes obligatoorsete määrusteta intransitiivsete tegusõnadega. Eesti grammatikatraditsioonis ei vaadelda aga kaudsihitist transitiivsusega seonduvalt.

Korpuseotsingud kinnitavad, et rangelt intransitiivsete verbide rühma kuuluvad veel näiteks jääma, sadama, algama, lõppema, jätkuma, vähenema, suurenema, sõltuma, olenema. Peale viie testitud verbi on Anne Tamm (2012: 131-136) nimetanud selle rühma verbidena ka selliseid verbe nagu süvenema, kontsentreeruma, veenduma, abielluma, kihluma, keelduma, veenduma, alluma, sukelduma. Nende kohta ei leidunud korpuses ei sisaldussihitisega ega ebatüüpilise objektiga kasutusjuhte. 


\section{2. Üldiselt intransitiivsed verbid}

Teises verbirühmas on analüüsitud tegusõnu kukkuma, jooksma, magama, laulma ja tantsima. Arvulised tulemused on koondatud tabelisse 2.

Tabel 2. Verbide kukkuma, magama, jooksma, tantsima ja laulma esinemine sihitisega 500 korpuselauses

\begin{tabular}{|l|c|c|c|}
\hline Tegusõna & $\begin{array}{c}\text { Sihitisega kasutusjuhtude } \\
\text { arv: sisaldussihitis / } \\
\text { ebatüüpiline objekt }\end{array}$ & $\begin{array}{c}\text { Semantiliselt } \\
\text { transitiivsed } \\
\text { kasutusjuhud }\end{array}$ & $\begin{array}{c}\text { Analüüsiks } \\
\text { mittesobivate } \\
\text { lausete arv }\end{array}$ \\
\hline kukkuma & $0 / 6$ & 1 & 7 \\
\hline magama & $10 / 21$ & 4 & 2 \\
\hline jooksma & $32 / 12$ & 3 & 8 \\
\hline tantsima & $70 / 11$ & 2 & 4 \\
\hline laulma & $164 / 12$ & 1 & 1 \\
\hline
\end{tabular}

Verbi kukkuma puhul esines analüüsitud materjalis mitmeid analüütilisi verbe, nt kokku kukkuma, läbi kukkuma, välja kukkuma, ära kukkuma, maha kukkuma, sisse kukkuma, katki kukkuma, lõhki kukkuma. Lihtverbil kukkuma eristus mitu tähendust: vanur lennuk hind jms kukkus ('kukkus maha või alla'), auhind kukkus ('saadi ootamatult kätte'), kell tähtaeg kukub ('jõuab varsti kätte'), kukkus sõimama ('hakkas'). Ebatüüpilist sihitist esines materjalis vaid analüütiliste verbidega katki kukkuma ja lõhki kukkuma (13-15). Korpuse lisaotsingud näitasid, et põhitähenduse 'maha või alla kukkuma' korral esineb ka lihtverb kukkuma sisaldussihitise (16) ning ebatüüpilise objektiga latiivsete koha- või seisundimääruste lisamisel, nt (17-19). Ebatüüpiline või sisaldusobjekt esineb sealjuures vaid elusa subjekti korral (vt ka Tamm 2012: 129-131).

(13) Kui katki sa end kukuksid, kui sa üritaksid teha veerandi sellest, mida tema rulal või laual teeb?

(14) Lauri väitis, et oli kukkunud peaga paviljoni klaasi katki.

(15) Kui lapsepõlves põlvi lõhki kukkusime, öeldi ikka: varesele valu, harakale haigus.

(16) Ma ei olnud oma lastega pooltki selline kanaema, nad said täitsa rahulikult turnida oma turnimised ja kukkuda oma kukkumised. 
(17) Kas te, ratturid, olete hullud, et kukute end koomasse, aga niipea kui pilt taas ees, hüppate kohe sadulasse, kuigi luud pole veel korralikult kokkugi kasvanud?

(18) Libedatel Moskva tänavatel libastus ja kukkus end vigaseks 454 inimest.

(19) Issi, ma vist kukkusin pesuresti kõveraks.

Samuti esines verbiga kukkuma sihitiselaadseid adverbiaale ehk osmasid, nt aktsiakurss kukkus 62\%, kukkus 49 korrust, kukkus vabalt 4 sekundit, ning transitiivsel kasutusel põhinevat tud-tarindit, nt siniseks kukutud puus.

Verbi magama puhul esines sisaldussihitis (nt talveund $\sim$ õndsat ja kosutavat und $\sim$ päevauinakut esimese osa uneööst) kümnel korral. Ebatüüpilise objekti kasutusjuhud $(\mathrm{n}=21)$ olid seotud analüütiliste verbidega (nt magas võimaluse maha; oleks hea, kui oleks võimalik peojärgne päev lihtsalt maha magada,/--/ kas laps laseb mul kuni lõunani voodis viimast mohiitot välja magada?). Maha magama puhul on võimalik nullobjekt (nt Ära maga maha_!), verbi välja magama kasutatakse sageli ka ilma subjektiga samaviitelise objektita (nt tuleb lihtsalt välja magada), mis annab põhjuse väita, et see on refleksiivselt labiilne verb. Lisaotsingutega leidus ka mitmeid lihtverbi laiendavaid ebatüüpilisi objekte koos translatiivse laiendiga (nt magas end kaineks $\sim$ terveks, magas pea selgeks).

500 lauses esines neljal korral semantiliselt transitiivset kasutust, nimelt passiivi või tud- ja mata-tarindit atribuudi funktsioonis (mil on unetunnid täis magatud, kahest magatud tunnist, magamata öö), ning 16 korral nominalisatsiooni (magama minek, magama jäämine). Ühel korral oli lauses ühendatud osma ja sisaldusobjekt (20).

(20) Et siis saabudes päikese käes oma 18 tundi kohustuslikku und ära magada.

Erinevalt verbidest kukkuma ja magama on tegusõnaga jooksma väljendatud tegevus elusa subjekti korral üldjuhul tahtlik. Samas on jooksma puhul võimalikud mitmed mitteelusad subjektid: film $\sim$ video $\sim$ pilt jookseb, veri $\sim$ vesi jookseb, toru $\sim$ mootor jookseb, töötasu $\sim$ toetuseraha jookseb, sulg $\sim$ jutt jookseb jms. Nendes tähendustes ei esine subjekti mitteagentiivsuse tõttu sisaldussihitist ega ebatüüpilist objekti.

Sisaldusobjekti rollis olid verbiga jooksma järgmised nimisõnafraasid: (pool)maraton, oma jooks, oma tee, (au)ring, (üks) tiir, lõigud, pikk maa, Heraklese jala pikkuse järgi mõõdetud distants, finaal, esimene vahetus, 
tavapärane trajektoor, kogu rada, need 3 kilomeetrit, 100 meetrit vm spordiala nimetus. Kahel korral oli sisaldussihitisega kasutatud analüütilist verbi läbi $\sim$ ära jooksma. Kokku esines sisaldusobjekt verbiga jooksma 32 korral. Peale sisaldussihitise esines kolmel korral adverbiaalifraasi millegi vahet jooksma ja kaheksal korral kvantumiosmasid, nt jooksis 12 kilomeetrit.

Juhul, kui sihitise rollis on spordiala nimetus või mingi konkreetne jooksusündmus (nt maraton), võib objektita kasutuse puhul olla tegelikult tegemist definiitse nullobjektiga (21).

(21) Lisaks temale on tänavu alla 10 sekundi _ jooksnud vaid ameeriklane Maurice Greene. [100 meetrit]

Neljal korral esinenud väljendid suu jookseb vett, silmad jooksevad vett ja nina jookseb verd arvestasin ebatüüpiliste objektide hulka. Nende puhul väljendab grammatiline sihitis tegevussubjekti ja alus tegevuskohta (vt Metslang 2017: 261). Kahel korral esines refleksiivset objekti (end pildituks surnuks jooksma) ja kahel korral sihtseisundit näitavat määrust (22, 23). Neljal korral kasutati koos analüütilise verbiga ebatüüpilist objekti (nt suudavad vastased üle joosta, jooksed ühe rekordi vähemalt ära, jooksis finaalis aja X välja). Kokku esines ebatüüpilist objekti 12 korral.

(22) „Nii kiire tüdruk ka pole, et kõik pallid eeskäele joosta,“ muigas Kivistik.

(23) Anu, sul on olnud 2 kontserti, mis on peaaegu pooleli jäänud, sest rahvas on sind pikali jooksnud.

Tegusõnade 'laulma' ja 'tantsima' puhul pole keeleuurijatel ühte meelt, kas need on objektita kasutatavad transitiivsed või objektiga kasutatavad intransitiivsed verbid (vt põhjalikumalt Kitahara 2010). Ka eesti verbidega laulma ja tantsima on objekti esinemine päris sage. Samas laiendab neid tavaliselt kas sisaldussihitis või ebatüüpiline objekt ning selle poolest sarnanevad nad pigem intransitiivsete verbidega (vt Horita 1996). Nende kahe verbi testimine näitas, et 500 korpuselause seas esines tantsima objektiga 81 korral (16\%) ning laulma 176 korral (35\%), mida on siiski mõnevõrra vähem kui sihitiseta kasutatavate transitiivsete verbide puhul (vt osad 4.4 ja 4.5).

Tegusõna tantsima esines sisaldusobjektiga 70 korral ja ebatüüpilise sihitisega 11 korral. Kahel korral oli tegu mata-tarindi intransitiivse kasutusega, mis on semantiliselt transitiivne, nt jäi võiduvalss tantsimata, 
ning ühel korral oli lauses ühendatud osma ja sisaldusobjekt (tantsime 100 meetrit ,Tuljakut“ Eesti 100. sünnipäeva auks).

Sisaldussihitiseks oli üldjuhul tantsuliik või tants + täiend (nt tantsib valssi $\sim$ tangot $\sim$ balletti, tantsib võidutantsu $\sim$ hoogsat rahvatantsu), kuid ka roll (nt tantsib Valget Luike). Ebatüüpilise objektina esinesid ühendid tantsima mingi kehaosa trimmi, end soojaks tantsima, tantsima mured eemale välja, tantsima end otse järgmisse päeva, südant lõhkema tantsima, tantsima end Euroopa parimate profipaaride seas viiendaks, tantsima jalad katki ning ka kõik naispulmakülalised läbi tantsima. Mõistagi esines korpuses ka teisi ebatüüpiliste objektide variante verbiga tantsima, nt võib end, keha või riideid higiseks tantsida.

Verb laulma esines koos sisaldusobjektiga 164 korral, seejuures seitsmel korral oli tegu analüütilise verbiga kaasa laulma, järele laulma, ette laulma, läbi laulma või sisse laulma. Enamikul juhtudel oli sisaldussihitiseks laul + täiend, laululiik, laulu nimetus, roll, samuti (hitt)lugu, refrään, meloodia, viis, repertuaar jms. Kinnistunud ühenditest võib välja tuua selliseid nagu halleluujat $\sim$ hosiannat $\sim$ ülistust laulma, karaoket laulma, soolot $\sim$ duetti laulma, esimest tenorit ja taustavokaali laulma. Ebatüüpilise objektiga (kokku 12 lauset) leidus järgmiseid näiteid: laulis end vabaks, laulis südamed ja hinged soojaks, laulame tunded välja, laulis end laulu (maailma)kuulsaks inimeste südamesse, samuti üsnagi haruldasi kasutusjuhte $(24,25)$. Lisaotsingud näitasid, et korpuses on päris palju ka muid näiteid ebatüüpilise sihitisega, nt ilusaks laulma (laulsime ilma ilusaks), magama laulma (laulab last magama).

(24) Noorem õde Ita (14) õpib muusikakeskkooli 8. klassis tšellot, vend Alfons (8) klaveri eriala, poolteisene väikevend Ernst juba laulab end ka muusika poole.

(25) Kui me Tomi ja sõpradega püüame väge ja eneseleidmist laulda võimalikult kõigile-kõigile, siis /--/ [= püüame laulmisega anda väge ja eneseleidmist]

Nagu jooksma puhul on nullobjekt võimalik ka verbidega laulma ja tantsima (vrd ta tantsib hästi ja noorpaar tantsis_hästi [pulmavalssi]). Ühe käsitluse järgi võib regulaarse sisaldusobjektiga esinevate verbide (nt laulma ja tantsima) intransitiivseid kasutusjuhte üleüldse vaadelda kui implitsiitset sisaldusobjekti, mis on niivõrd iseenesest mõistetav, et seda ei peagi lauses väljendama (vt põhjalikumalt Velasco, Muñoz 2002). Nii võib oletada, et eesti verbide laulma ja tantsima puhul on aja jooksul toimunud 
kaks protsessi: 1) sisaldusobjekti väljajätt on muutunud nii regulaarseks, et neid verbe kasutatakse tänapäeval sagedamini intransitiivsena kui transitiivsena, 2) võimalike objektide laienemine hüponüümia ja analoogia alusel (nt tantsib Musta Luike, laulab karaoket). Kui esimese protsessi toimumisest või mittetoimumisest saab rääkida vaid pärast vastavaid diakroonilisi uurimusi, siis teine protsess on kindlasti toimunud.

Tegusõnad laulma ja tantsima on üsnagi sarnased 4. ja 5. rühma verbidega sööma ja jooma, mille puhul on sihitise rollis samuti sageli hüponüümia või analoogia alusel laiendatud sisaldusobjektid (vrd sööb sööki ja sööb võileiba, sööb lõunat) või ebatüüpilised objektid (nt jõi end purju). Siiski on nende esinemine objektiga märgatavalt vähem sagedane (verb sööma esines 500 korpuselauses objektiga 58\% ja jooma $67 \%$ juhtudest, vt osad 4.4 ja 4.5). Samas eristuvad laulma ja tantsima teistest selles rühmas testitud tegusõnadest objektiga esinemise sageduse ja võimalike objektide arvu poolest ning jäävad seega rühma parempoolsesse perifeeriasse.

Teise kategooria verbide testimine näitas, et sisaldussihitist ja ebatüüpilist objekti võimaldavatel intransitiivsetel tegusõnadel võib olla väga erinev sihitisega seonduvuse määr. Siia rühma kuuluksid veel näiteks võistlema, kasvama, töötama, unistama, kohtuma, naeratama, elama, surema ning kindlasti ka paljud liikumisverbid, nt käima, ujuma, astuma, kõndima. Kõiki neid tegusõnu ühendab asjaolu, et enamasti võtavad nad agentiivse subjekti, mis võimaldabki liita sisaldussihitist ja ebatüüpilist objekti. Lisaks lubavad paljud selle rühma tegusõnad tõlgendada nendega väljendatud tegevust nii protsessi kui ka piiritletud sündmusena ${ }^{7}$, mille toimumise jooksul või selle tulemusena võib juhtuda mingi teine sündmus või kulgeda teine tegevus, nt kukkus telefoni katki, võistles end parimaks $\sim$ esiliigasse, laulab elu ilusaks.

Peab ka mainima, et osa siia kuuluvatest verbidest võib loomulikus või sageli ettetulevas kontekstis võimaldada kas pigem ainult sisaldussihitist või ainult ebatüüpilist objekti. Näiteks ei tundu verbi töötama puhul sisaldusobjekt loomulik. Korpusest õnnestus leida vaid üks näide: võib töötada mitut tööd. Samas oli väga palju ebatüüpilise sihitise näiteid, nt töötama end jõukaks haigeks silmist siniseks jms, ka töötama end liidriks tippu, töötama käed rakku vms. Kohtuma puhul leidus vaid üksikuid näiteid sisaldusobjektiga, nt laseme riigi parlamendi liikmetel

7 Paradoksina on protsessi tõlgendus võimalik ka momentaanse tähendusega verbi kukkuma puhul, nt kukkus 49 korrust. 
kohtuda oma kohtumisi. Seega moodustavad siia rühma kuuluvad verbid objektiga seonduvuse määra poolest justkui omaette kontiinumi, nt kohtuma $>$ töötama $>$ kukkuma $>$ magama $>$ jooksma $>$ tantsima $>$ laulma.

\subsection{Prototüüpselt ja polüseemselt labiilsed verbid}

Nagu saab järeldada eelmises osas käsitletud verbide kasutusjuhtude põhjal, ei või labiilne olla mitte ainult lihtverb, vaid ka analüütiline tegusõna, nt tass kukkus katki ja kukkus tassi katki, magas välja ja magas väsimuse välja. Selles osas vaatlen, kui sagedad on prototüüpselt labiilsete tegusõnade rõ̃̃mustama, jalutama, pöörama, suudlema ja P-labiilsusega polüseemse tegusõna mängima transitiivsed ja intransitiivsed kasutusjuhud (vt tabel 3).

Tabel 3. Verbide rõ̃̃mustama, jalutama, pöörama, suudlema ja mängima esinemine 500 korpuselauses

\begin{tabular}{|l|c|c|c|}
\hline Tegusõna & $\begin{array}{c}\text { Sihitisega } \\
\text { kasutusjuhtude } \\
\text { arv }\end{array}$ & $\begin{array}{c}\text { Sihitiseta kasutusjuhtude } \\
\text { arv (sh nullobjekt / muud } \\
\text { semantiliselt transitiivsed } \\
\text { kasutusjuhud) }\end{array}$ & $\begin{array}{c}\text { Analüüsiks } \\
\text { mittesobivate } \\
\text { lausete arv }\end{array}$ \\
\hline rõõmustama & 163 & $336(35 / 1)$ & 1 \\
\hline jalutama & 13 & $484(0 / 2)$ & 3 \\
\hline pöörama & 414 & $84(7 / 19)$ & 2 \\
\hline suudlema & 316 & $177(31 / 3)$ & 7 \\
\hline mängima & 243 & $253(181 / 4)$ & 4 \\
\hline
\end{tabular}

P-labiilsel tegusõnal rõ̃̃mustama on intransitiivne paariline rõõmustuma, mis ei ole tänapäeva eesti keeles sageda kasutusega. Nii leidub 2019. aasta eesti keele ühendkorpuses vaid 182 lauset tegusõnaga rõõmustuma ning 66008 lauset tegusõnaga rõ̃mustama.

Rõõmustama puhul oli 500 korpuselause hulgas 300 sihitiseta kasutusjuhtu, mida saab lugeda süntaktiliselt ja semantiliselt intransitiivseks (60\%). Rõomustama-verbi intransitiivsete kasutusjuhtude seas oli järgmiseid korduvaid malle: X rõõmustab millegi üle $\sim$ pärast $\sim$ puhul $\sim$ eest, $X$ rõõmustab, et ... sest ... $\sim$ kui $\ldots, X$-il on põhjust rõõmustada, on vara rõõmustada, X rõõmustab nagu Y(ki), X rõõmustab kaasa koos Y-iga, 
$X$ rõ̃mustab väga $\sim$ meeletult $\sim$ südamest, kuidas $X$ küll rõ̃omustas, $X$ rõõmustab kellestki. Samuti avaldub intransitiivne kasutus imperatiiviga (sageli koos sõnaga ometi või üttega, nt Rõõmusta ometi!. Ristirahvas, rõomusta!), kahe või enama verbi korral (nt kas nutta või rõõmustada), ning otsekõnega (26). Kõige regulaarsemad mainitud mallidest olid rõõmustama millegi üle ning esinemine koos kõrvallause ja otsekõnega.

(26) „Elu on märksa lihtsamaks läinud,“ rõõmustab Pille.

Sihitisega kasutusjuhtudes $(\mathrm{n}=163)$ esines nii elusaid objekte, sh refleksiivne end, kui ka ülekantud tähenduses elutuid sihitisi, nagu rõõmustab südant $\sim$ silma $\sim$ hinge $\sim$ meeli. Sageli laiendas transitiivset lauset ka komitatiivne laiend.

Nullobjekti korral $(\mathrm{n}=35)$ olid kõige regulaarsemateks järgmised mallid: (eriti) rõõmustas see, et ..., paneb rõõmustama ning pole midagi rõõmustavat või muu $v$-kesksõna kasutus. Materjalis esines nii definiitset kui ka indefiniitset nullobjekti, kuid mõnikord oli raske nende vahele piiri tõmmata. Neljal korral oli tegemist loomuliku nullobjektiga, nt ta võib neid välja vihastada või hoopis _ rõõmustada.

A-labiilse tegusõnaga jalutama oli 500 korpuselauses 13 sihitisega kasutusjuhtu ( ca 3\%), millest vaid viis olid tähendusega 'koera last $\sim$ hobust jalutama' (27). Koera jalutamise puhul oli materjalis palju sagedasem komitatiivne rektsioon: 'koera jalutama' esines kolmel korral ning 'koeraga jalutama' 14 korral. Neid kahte sünonüümset sõnastust peaks semantilisel tasandil eristama see, et sihitisega konstruktsioon lisab olukorrale aspektuaalse piiri võimaluse.

(27) Eriti lahe oli Linda jaoks see, et pisemat „auat“ sai ta ka ise jalutada.

Kaheksal korral 13st esines tegusõna jalutama sisaldusobjektiga, sh analüütiliste verbide puhul, nt jalutavad oma koertega pikki distantse, negatiivsed mõtted jalutavad oma rada, tigu võib öö jooksul läbi jalutada terve väikese aia. Peale sihitise kasutati jalutama-verbi ka kvantumiosmadega (lehmakari oli jalutanud kodust 3-4 kilomeetrit, rongijaamast on järveni natuke maad jalutada) ja adverbiaalifraasis millegi vahet jalutama. Kahel korral oli olukord semantiliselt transitiivne, nt koer peab saama jalutatud.

Lisaotsingud korpusest näitasid, et ka analüütiline tegusõna ära jalutama on A-labiilne, vrd nt Ta keeras selja ja jalutas ära ning Kas tuba on ära koristatud ja koer ära jalutatud?. Nagu ka jalutama puhul 
on verbiga ära jalutama transitiivne kasutus palju haruldasem. Mitteagentiivse subjekti korral võib intransitiivses kasutuses olla ka ülekantud tähendus, nt (28).

(28) Kuusemüüja sõnul peab valvas olema ka päeval, sest vahel kipuvad mõned kuused ära jalutama.

Refleksiivselt labiilse tegusõna pöörama puhul oli ülekaalus sihitisega kasutus ( ca 83\%), sh tänu leksikaliseerunud ühendi tähelepanu pöörama sagedusele. Süntaktiliselt ja semantiliselt intransitiivsete kasutusjuhtude korduvateks mallideks olid nt kuhugi poole pöörama, ümber $\sim$ ringi pöörama, tülli pöörama, kellegi vastu pöörama. Intransitiivsed on ka ülekantud tähendusega kasutusjuhud sulale pöörama ja sees pöörab (iivelduse kohta). 19 korral oli tegu semantiliselt transitiivse olukorraga (nt põhjuse ja tagajärje seos on pahupidi pööratud, kaetud pööratud nahaga jms) ning kuuel korral nullobjektiga. Definiitset nullobjekti esines korduvalt kudumise valdkonnas, nt pööra _, tõsta 1 silmus kudumata ja koo 10 silmust rohkem. Võib oletada, et ka tähenduses 'tegusõnu pöörama', mida analüüsitud materjalis ei leidunud, on samuti võimalik vaid definiitne nullsihitis. Osal juhtudest esines loomulik nullobjekt, nt võimaldavad suumida, pöörata _ ja kuvada oma tööd spetsiaalse varjurežiimiga.

Mõnikord oli sihitiseta kasutuse puhul põhimõtteliselt võimalik nii transitiivne kui ka intransitiivne tõlgendus (29). See näitab, et refleksiivselt labiilne pöörama-verb võimaldab mõne kindla objekti puhul ka P-labiilsust (vrd ka pööran autot paremale - auto pöörab paremale).

(29) /--/ noorte elu võib paremuse poole pöörata vaid siis, kui riigi majanduslik ja poliitiline kurss kardinaalselt välja vahetada.

Niisiis näitas tegusõna pöörama testimine, et see on polüseemne verb, mis võimaldab mitmesugust transitiivset ja intransitiivset kasutust, sh refleksiivset ja P-labiilset. Samuti oli pöörama puhul võimalik analüütiliste verbide ambitransitiivne kasutus, nt /--/ kui too /--/ sind uude kulinaarsesse usku ei pööranudki (transitiivne); siiani on kõik uskmatud usku pööranud, pöörate ka teie /--/ (intransitiivne); pööras ära ja nägi, et /--/; enamik endisi kaasvõistlejaid on temast ära pööranud; ilm pööras külmaks ära, ta on täitsa ära pööranud ('hulluks läinud') (intransitiivne); mängimise ajal ei saa mängurit ära pöörata, pööras pilgu ära (transitiivne). 
Retsiprookselt labiilse tegusõna suudlema testimine näitas, et 500 lause seas oli rohkem sihitisega kasutusjuhte ( ca 63\%). Sihitiseta kasutamisel $(n=177)$ oli üsnagi sageli raske määrata, kas tegu on nullobjekti või intransitiivse kasutusega, v.a juhud, kus on olemas intransitiivsed (omavahel kellegagi suudlema) või transitiivsed markerid (nt suudles põsele kummalegi poole, suudles vastu, suudlen kirja või sõnumi lõpus või muu kontekstisidus viide definiitsele nullobjektile), vrd nt (30), (31) ja (32), (33).

(30) Ma olin 13 (umbes kuu aega tagasi sain), kui esimest korda suudlesin. [?kellegagi, ?kedagi]

(31) Ta ei tulnud enam suudlema, ta läks nüüd päris tõesti uksest välja. [?mind, ?minuga]

(32) Ameeriklane võtab rahakotist 100 dollarit, suudleb _ ja viskab alla. [seda]

(33) Igavesti sinu, suudlen _, armastan. [sind]

Esmapilgul võib tunduda, et mitmusliku subjekti puhul on retsiprookne sihitiseta kasutus (nt Nad suudlesid) intransitiivne (nagu ka näiteks vene keeles), kuid eesti keeles on siiski võimalik kahesugune tõlgendus. Kirjeldatud transitiivsuse ebamäärasus tuleneb tegusõna suudlema sihitisega paralleelsest komitatiivsest rektsioonist.

Tegusõna mängima oli valitud testimiseks kui mitmetähendusliku labiilse verbi näide, mis võimaldab ka P-labiilsust. Korpusematerjali analüüs kinnitas, et mängima-verbi tähendused käituvad transitiivsuse seisukohalt erinevalt. P-labiilsus esineb vaid teatud hulga objektide korral, nt mängib muusikat - muusika mängib, mängib pilli - pill mängib, mängib plaati - plaat mängib, mängib videot - video mängib. Tähendused 'kindlat (spordi)mängu mängima', 'kedagi või midagi kehastama, rollis esinema, kellenagi käituma', 'muusikariista mängima' on üldiselt süntaktiliselt transitiivsed, kuid nende puhul on võimalik ka nullobjekt. Säärased sihitised ei ole aga täielikult tegevusega mõjutatud ning seega on Hopperi ja Thompsoni (1980) skaala järgi neid sisaldavad laused väiksema transitiivsusega. Kui objekti rollis on mingi mäng, siis on see pigem sisaldussihitis, ning kui muusikariist, siis pole see semantilises mõttes patsient, vaid instrument (mängib klaverit = mängib klaveril muusikat). Materjalis oli ka ebatüüpilisi objekte, nagu nt mängis külarahva üles, mängis palli auti, see võimaldas ennast mitmekesi üle võrgu mängida. 
Mängima-verbi puhul osutus sageli raskeks eristada nullobjekti muust süntaktiliselt intransitiivsest kasutusest. Mitmed sihitiseta kontekstid tunduvad pigem kinnistunud intransitiivsed kasutusjuhud kui nullobjekti juhud, nt teler $\sim$ raadio mängib, (seade) mängib siis kauem ('on kauem töökorras'). Leidub ka teisi leksikaliseerunud idiomaatilisi sihitiseta ütlusi, nagu aeg mängib meie kasuks meie vastu, on mille nimel mängida. Sellise kasutuse puhul ei tundu eksplitsiitse sihitise lisamine alati loomulik ning sageli pole see üldsegi mõeldav. Seepärast ei ole ma lugenud sääraseid kasutusjuhte nullobjekti hulka. Samas näitavad korpuseotsingud, et mõned loetletud kontekstidest võimaldavad siiski sihitise kasutust, nt Raadio mängib seda muusikat, mida ise tellite. Raadio mängib hümni. Muusikat teler mängib, aga keskmised toonid on kusagile kadunud. Tekib küsimus, kas siis Teler mängib on pigem kinnistunud intransitiivne kasutus, aga nt Paljud audiofilid eelistavad selliseid taasesitusseadmeid, mis mängivad puhtalt ka vaiksel helinivool on pigem nullobjekti juhtum. Siin võib lähtuda sellest, et paljude intransitiivsete kasutusjuhtude puhul on põhimõtteliselt võimalik asendada mängima-verbi teise verbi või fraasiga, nt teler mängib ('on sisse lülitatud, töötab'). Muusikavaldkonnas saab mõnes kontekstis asendada mängima-verbi tegusõnaga esinema (34).

(34) Esimest korda mängis TÜ sümfooniaorkester ülikooli publikule 26. mail 1956.

Kinnistunud intransitiivseks kasutuseks olen samuti pidanud komitatiivse laiendiga tähendusi 'nagu mänguasja käsitsema või kohtlema' (nt me ei tohi mängida oma demokraatiaga, mängisime tulega), 'loominguliselt lähenema' (nt annab võimaluse mängida ruumiga) ning ka juhud, kus oli elutu või väikese agentiivsusega subjekt või kontekst ei eeldanud mingit konkreetset mängu (nt Istmed tegelikult ilusad valged, seal valgus mängis imelikult. Kui lapsed magasid, mängisid akna taga oravad).

Samas ei ole mängimise kontekst alati transitiivsuse seisukohalt üheselt mõistetav. Kui kutsikas mängib peremehe jalgadega või omanik mängib oma kodulemmikuga, siis on selge, et see olukord ei eelda mingit kindlat mängu. Kas on aga vahet, kui lapsed mängivad näiteks õues või liivakastis, mängutoas ja mänguväljakul? Siin võib lähtuda loogikast, et kui laps mängib õues, võib ta lihtsalt üksi või sõpradega joosta, aga võib ka palli vm mängida. Kui laps mängib liivakastis, mängutoas või mänguväljakul, siis ei eelda need kontekstid tavaliselt kindlat mängu, vaid pigem kirjeldavad 
tegevust. Vastuväiteks saab aga öelda, et mängutoas võib näiteks peitust mängida, liivakastis poodi mängida jms. Kui kontekst (sh eelnev või järgnev) ei eeldanud mingit konkreetset mängu, olen siiski liigitanud säärased juhtumid süntaktiliselt ja semantiliselt intransitiivse kasutuse alla.

Nullobjekti ja kinnistunud intransitiivse kasutuse eristust silmas pidades pole alati selge ka paralleelse, muu kui sihitise rektsiooni kasutus mängima-verbiga. Ühelt poolt on nt mängib viiulit, mängib viiulil ja mängib viiuliga täiesti sünonüümsed, teiselt poolt saab kahe viimase fraasi puhul lisada täiendiga sihitise, nt mängib viiulil viiuliga ilusat muusikat. Samamoodi saab ka fraasi mängib peaosas puhul (vrd mängib peaosa) öelda nt mängib peaosas teiselt planeedilt tulnud meest. Materjalis esinenud viiuliga mängima $(\mathrm{n}=1)$ ja peaosas mängima $(\mathrm{n}=1)$ arvestasin seega siiski nullobjektide hulka, nagu ka teised n-ö kinnistunud kasutusjuhud spordi-, teatri- ja muusikavaldkonnas: mängib kaitses $\sim$ tagaliinis $\sim$ ründajana, Eesti mängib täna võorsil Kreekaga Kreeka vastu, mängib bändis X, tantsuks mängib ansambel X, lavastaja X, mängivad Yja Z. Lisaotsinguga olen korpusest leidnud ka muu kui sihitise rektsiooniga piltlikku kasutust, nt reklaam mängib emotsioonidel; põhiline, millele reklaamis mängitakse, on jooginimi, mis tunduvad pigem ka semantiliselt intransitiivsed.

Alati polnud kerge eristada ka definiitset ja indefiniitset nullobjekti. Indefiniitsete nullobjektide näiteks võib tuua järgmised esinemisjuhud geneerilist või teatud tüüpi objekti eeldatavas kontekstis, nt kui mängida, siis ausalt; käin FB-s ainult mängimas; lapsed tahaksid koju jõudes telefonis mängida või telerist multikaid vaadata; peretütar istus klaveri taha ja hakkas mängima.

Umbes pool 500 korpuselausest oli eksplitsiitse sihitisega. Nende hulgas leidus samuti kinnistunud ühendeid, nagu olulist $\sim$ tähtsat rolli mängima, suurt osa mängima, kellelegi vingerpussi mängima.

Selle rühma verbide testimine näitas, et labiilsetel verbidel võib olla ülekaalus kas transitiivne või intransitiivne kasutus ning peale kindla labiilsustüübi võib tegusõnal olla ka teisigi transitiivseid ja intransitiivseid kasutusjuhte. Sageli on ambitransitiivse kasutuse põhjuseks verbi polüseemsus. Polüseemsete verbide puhul tuleks siiski vaadelda igat konkreetset tähendust või kasutust eraldi. Oma kahesuguse kasutuse poolest paiknevad prototüüpselt ja polüseemselt labiilsed verbid transitiivsuse skaalal intransitiivsete ja transitiivsete verbirühmade vahel, olles sageli lähedasemed kas eelmisele või järgmisele verbirühmale. 
Vaatlusalusesse rühma kuuluvad veel näiteks polüseemselt labiilsed verbid pü̈̈ma (vt näited osas 1), aitama (aitab küll, aitab naljast, aitab seljavalu vastu korral (intransitiivne), aitab sõpra, aitab sõbral õppida (transitiivne)), lahutama (abielu lahutati, lahutage viiest kaks, lahutab käsi, lahutab meelt (transitiivne), abielupaar lahutas, mees lahutas oma naisest (intransitiivne)).

\subsection{Intransitiivsena kasutatavad transitiivsed verbid}

Selle rühma tegusõnade puhul tõstab sihitiseta kasutus fookusesse verbiga väljendatud tegevuse. Objekti eksplitsiitne väljendamine pole seejuures vajalik või tähtis.

Analüüsi eesmärk oli vaadata, kui tihti ja mis kontekstides esinevad verbid sööma, koristama, ómblema ja kirjutama sihitiseta. Ilmnes, et mõnevõrra rohkem oli objektita näiteid verbidega harjutama, sööma ja koristama ning mõnevõrra vähem verbidega kirjutama ja õmblema (vt tabel 4), kuid keskmiselt oli selles kategoorias sihitiseta esinemisjuhte $30-40 \%$.

Tabel 4. Verbide sööma, harjutama, koristama, kirjutama ja õmblema esinemine 500 korpuselauses

\begin{tabular}{|l|c|c|c|}
\hline Tegusõna & $\begin{array}{c}\text { Sihitisega } \\
\text { kasutus- } \\
\text { juhtude arv }\end{array}$ & $\begin{array}{c}\text { Sihitiseta kasutusjuhtude } \\
\text { arv (sh nullobjekt / muud } \\
\text { semantiliselt transitiivsed } \\
\text { kasutusjuhud) }\end{array}$ & $\begin{array}{c}\text { Analüüsiks } \\
\text { mittesobivate } \\
\text { lausete arv }\end{array}$ \\
\hline sööma & 284 & $212(162 / 4)$ & 4 \\
\hline harjutama & 285 & $214(206 / 5)$ & 1 \\
\hline koristama & 292 & $205(152 / 53)$ & 3 \\
\hline kirjutama & 335 & $146(97 / 49)$ & 19 \\
\hline omblema & 355 & $145(138 / 7)$ & - \\
\hline
\end{tabular}

Tegusõna sööma oli 46 korral seotud esinemisjuhtudega, kus sööma oli kas analüütiliste verbide süüa tegema süüa valmistama vms osa, substantiivifraasi osa (nt enne sööma asumist) või oli seda kasutatud substantiivi funktsioonis (nt külmikus peaks midagi süüa olema, raha eest on võimalik süüa osta, koerale süüa viies, kui hästi ja maitsvalt tädi pool alati süüa sai). Kui objekt võiks laiendada verbivormi süüa (mitte 
ei asendaks seda), arvestasin eelmistega sarnased juhud (nt sai kolm korda päevas tasuta süüa [nt suppi], andsin kaladele sü̈̈a [nt sööta]) nullobjektide hulka. Neljal korral viitasid semantilisele transitiivsusele väljendid kõlbab süüa, jätavad koolitoidu söömata vms. 162 korral oli tegu nullobjektiga, millest definiitse objekti väljajätte oli vaid 13. Sihitiseta esines sööma-verb tihti 1) ma- ja da-infinitiivi juures (nt hakkas sööma, tuli sööma, ei taha süüa jms), 2) mas-, mata-ja des-tarindis (nt käivad vabal päeval koos söömas; seda peab tegema söömata; lapsed ei saa süües arugi, et neis köögiviljad on), 3) imperatiivi vormis (nt söö mõõdukalt) ja 4) kinnistunud rindühendis (nt söövad ja joovad). Tavalisimad lauseelemendid, mis lisasid konteksti ja aitasid tegevuse fookusesse tõsta, olid erinevad kohamäärused (kutsuti restorani sööma, sõime väljas $\sim$ Kuuba restoranis, süüakse ühest toidunõust jms), kuid ka instrumenti tähistavad ning viisi-, aja-, hulga-, kestus- ja muud määrused (nt süüakse lusikaga nagu kiivit; ei söö iseseisvalt; hommikul ma ei söö; söön imevähe;/--/ olles ise enne seda kaks tundi järjest söönud). Samuti soodustasid nullobjekti habituaalne tegevus (nt lasteaialapsed söövad kolm korda päevas) ning kahe või enama tegevuse seostamine $(35,36)$.

(35) Ärkasin hommikul kell kaheksa, käisin duši all, sõin, vaatasin televiisorit ja tulin kooli.

(36) Kui meie isaga olime söönud, lubas ta teised laua äärde.

Verb harjutama esines sihitiseta kõige sagedamini kas sporditeemalistes lausetes tähenduses 'trenni tegema' või muudes valdkondades tähenduses 'praktiseerima, treenima'. Harjutama kui 'trenni tegema' tundub leksikaalselt kinnistunud nullobjekti kasutus. Sihitise lisamine lausetesse nagu (37) ja (38) pole loomulik, kuid mitte välistatud.

(37) Harjutasin kaks kuud Keenias, olen võistluse heaks teinud kõik, mida vaja $/--/$.

(38) Noole kergejõustikukoolis harjutab 152 last.

Ka tähenduse 'praktiseerima, treenima' puhul jäetakse sageli sihitis lausesse lisamata, kuid soovi korral on selle lisamine võimalik ja loomulik $(39,40)$.

(39) Pulkadega ma eriti osav ei ole, aga küll harjutan.

(40) Harjuta demokontodega. 
Analüüsitud materjalis leidus kausatiivse tähenduse juures harjutamaverbiga ka definiitseid nullobjekte (nt mida suuremaks saab, seda raskem on harjutada_oma voodiga [last]). Sihitise asemel kasutati kolmel korral $m a$-infinitiivi (nt kõik harjutasid seal lahaseid panema). Viiel korral esines harjutama verb semantiliselt transitiivses kontekstis (nt evakuatsiooniplaan on harjutatud, välisõhuga harjutatud taimed).

Tegusõnade koristama ja õmblema sihitiseta esinemise süntaktilised mallid ja kontekstid olid üldjoontes samad mis sööma-verbil, nt koristama: ei viitsi ei jõua koristada; jään täna koju koristama; käis siin aeg-ajalt koristamas; võid panna mängima lemmikmuusika ja koristades tantsida; ma koristan alati öösiti; nüüd koristame kõik koos; vaatab lapsi, teeb süüa ja koristab; kui koristan, kuulan hoogsat muusikat; koristan senikaua, kuni maha rahunen; õmblema: oskan natuke õmmelda; õmblen endale $\sim$ heategevuseks $\sim$ masinal $\sim$ teki tehnikas; vanemad nägid rohkesti vaeva: kes ómbles, kes joonistas, kes värvis poole ööni, et lapsel oleks tore võlurite päeval olla. Koristama puhul asendab sihitist tihti tegevuskoht (nt koristasin garaažis, tema kodus koristab ema). Analüüsitud keelematerjalis oli päris sage ka kinnistunud nullobjekti kasutus 'koristama enda või teiste järelt $\sim$ järgi $\sim$ tagant'. Nii koristama kui ómblema puhul on võimalik ka elutu subjekt (nt tolmuimeja koristab korralikult, ómblusmasin enam ei õmble). Koristama puhul oli 152 implitsiitse sihitise juhu hulgas 21 definiitset nullobjekti, sh tähenduses 'vilja või heina koristama', 'midagi eest ära koristama'. Õmblema puhul leidus 78 definiitset nullobjekti 138st, eelkõige analüütiliste verbidega kokku õmblema, kinni õmblema ja läbi ómblema ning lihtverbiga tähenduses 'mingit kehaosa kinni õmblema' (nt Ma läksin traumapunkti õmblema _ [haava]).

Tegusõna kirjutama kasutati sihitiseta kõige sagedamini kontekstides 'millestki v millegi kohta kirjutama', 'mingil teemal kirjutama', 'kellelegi v kuhugi kirjutama' (nt sellest ei taheta eriti kirjutada; kirjutasin sel teemal eelmisel aastal; kirjuta mulle julgelt; lisainfo saamiseks helista või kirjuta meile; kirjuta Facebooki), samuti 'mingis keeles kirjutama', 'õppima lugema ja kirjutama' ning nagu Xjuba kirjutas, nii nõnda kirjutas $X$, üles kirjutanud $X$. Lisaks aitasid tegevust fookusesse tõsta eri liiki määrused, nt kirjutan kunagi pikemalt, kirjutan mõne aja pärast enam, kirjutab seosetult, raske on midagi arvata, kui kirjutatakse niivõrd vähe. Kirjutama puhul ei olnud alati kerge määratleda, kas tegemist on definiitse või indefiniitse nullsihitisega, kuid enamasti esines siiski indefiniitse 
objekti väljajätt. 49 korral oli tegu semantiliselt transitiivse kasutusega, nagu Kas linna nimi on õigesti kirjutatud?.

Selle rühma tegusõnade iseloomulik joon on see, et nad võimaldavad regulaarseid indefiniitseid nullobjekte. Testimiseks, kas verb kuulub siia või järgmisesse verbirühma, võib pakkuda malli 'mulle meeldib $\sim e i$ meeldi, ma oskan hästi ei oska vms + testitav tegusõna' ilma lisakontekstita ja tähenduse muutmiseta. Nagu ka eelmise rühma puhul, on paljud siia kuuluvad verbid polüseemsed, kuid erinevalt eelmisest rühmast pole neil prototüüpse labiilsuse tunnuseid ning kõik tähendused haakuvad üksteisega. Mõnel selle rühma verbidest on eristumas regulaarsed intransitiivsed kasutusjuhud või alltähendused, mis on järgmise verbitüübi iseloomulikuks jooneks. Eriti paistab see silma harjutama-verbi tähenduse 'trenni tegema' puhul, mis annab põhjuse väita, et see tegusõna jääb justkui neljanda ja viienda verbirühma vahepealseks juhtumiks.

\section{5. Üldiselt transitiivsed verbid}

Siia rühma kuuluvad tegusõnad, millel on paralleelne, muu kui sihitise rektsioon ja/või regulaarseks muutunud sihitiseta alltähendus(ed) või kasutusmall(id). Vaatluse all on verbid alustama, jätkama, lõpetama, jooma ja nägema, mille puhul fikseerisin kõik sihitiseta esinemise juhud (vt tabel 5).

Tabel 5. Verbide alustama, jätkama, lõpetama, jooma ja nägema esinemine 500 korpuselause seas

\begin{tabular}{|l|c|c|c|}
\hline Tegusõna & $\begin{array}{c}\text { Sihitisega } \\
\text { kasutus- } \\
\text { juhtude arv }\end{array}$ & $\begin{array}{c}\text { Sihitiseta kasutusjuhtude } \\
\text { arv (sh nullobjekt / muud } \\
\text { semantiliselt transitiivsed } \\
\text { kasutusjuhud) }\end{array}$ & $\begin{array}{c}\text { Analüüsiks } \\
\text { mittesobivate } \\
\text { lausete arv }\end{array}$ \\
\hline alustama & 284 & $209(193 / 9)$ & 7 \\
\hline jätkama & 307 & $192(192 /-)$ & 1 \\
\hline löpetama & 370 & $126(80 / 19)$ & 4 \\
\hline jooma & 341 & $152(129 / 12)$ & 2 \\
\hline nägema & 436 & $62(42 / 19)$ & 7 \\
\hline
\end{tabular}


Tegusõnad jätkama, alustama ja lõpetama olid valitud testimiseks mitmel põhjusel: 1) faasiverbid on paljudes keeltes labiilsed või labiilsusele kalduvad (vt nt Letuchiy 2013), 2) varasemate teemade korpusepõhisel uurimisel olen tähele pannud, et jätkama-verb esineb tihti sihitiseta kinnistunud kontekstides, nt jätkab oma ametis, 3) oli huvitav näha, kui palju on nullsihitise kasutamisel ühte semantilisse klassi kuuluvatel verbidel sarnast või erinevat. Selgus, et kõiki kolme verbi kasutatakse tihti nullobjektiga spordivaldkonnas (nt lõpetas kolmandana isikliku rekordiga, pühapäeval peetud viimasel etapil alustasid naised, jätkab 20 punktiga 12. kohal) ja otsekõnega, mis oli eriti regulaarne $(\mathrm{n}=18)$ jätkama puhul (41).

(41) „Ma tean, et see kõlab teile uskumatuna“, jätkas_Rian vaikselt. [juttu] Kolme analüüsitud faasiverbi puhul soodustas nullobjekti sageli komitatiivne laiend $(42,43)$ ning alustama ja jätkama puhul ka elatiivne laiend, sh leksikaalselt kinnistunud ütlustes, nt alustaks iseendast, tuli alustada nullist, alustasin A-st ja B-st, alusta otsast peale, ei oska kuskilt alustada, jätkas samast kohast, jätkatakse seisult 1:0. Komitatiivne laiend esines mõnikord ka justkui tegevusobjekti rollis (vt põhjalikumalt Metslang jt 2017), nt jätkab eluga, alustab taas treeningutega, ehkki määruse ja tegevusobjekti vahe ei olnud terav, nt alustas tabletikuuriga [= alustas tabletikuuri, kuid ka alustas ravi tabletikuuriga], alustab taas treeningutega [= alustab taas treeninguid, kuid on põhimõtteliselt võimalik ka alustab taas treeningutega tervisliku eluviisi pidamist],jätkab eluga [= jätkab oma elu, kuid võimalik on ka jätkab eluga edasiliikumist]. Seepärast lugesin kõik säärased juhtumid siiski leksikaalselt kinnistunud nullobjekti alla. Kahtepidi mõistetavust tingivad siin verbidele omane sihitisega paralleelne rektsioon ning keele ökonoomsuse printsiip.

(42) Medici purskkaev on rajatud 1630. aasta paiku, siis, kui Marie de' Medici eestvõttel ehitati Luxembourgi paleed ja alustati_suurejoonelise pargiga.

(43) Kui olevused on Bowmaniga_ lõpetanud, saadetakse ta justkui mõne superolevusena tagasi Maale.

Peale selle, et nullsihitis esines koos otsekõnega, kus objekti rollis oli nimisõna jutt vms, kasutati seda regulaarselt ka koos välja jäetud objektiga töö, tegevus, harjutamine vms (44-47). Mõnes kontekstis oli põhimõtteliselt võimalik asendada transitiivne verb intransitiivsega $(48,49)$. 
Sageli esines koos nullsihitisega essiivne laiend, nt alustas katlakütjana, Stavanger alustab Euroopa kultuuripealinnana,jätkas liidrina. Lõpetama ja alustama puhul esinesid nullobjekti rollis ka nimisõnad õpingud, kool vms, nt vaevalt ta kahe aastaga lõpetab; saja viiekümnest inimesest, kes koolitusel alustasid, jõudis eksamile sadakond.

(44) Admiral Club lõpetab.

(45) IRLi ministrid jätkavad kuni uute ministrite ametisse astumiseni.

(46) Ma ise olen alustanud Prisma kassast, meie müügidirektor ja mitmed meie kaupluse juhatajad on alustanud Prisma kassast.

(47) Alustasin nöörrajal 6aastasena.

(48) Eelkool alustab 4. oktoobrist.

(49) Möödunud nädalal vaatajad telerite ette naelutanud uus kodumaine krimidraama „Nukumaja“ jätkab küsimuste ja kahtlustega Kanal 2 ekraanil juba täna kell 21:30.

Nagu ka eelmise verbirühma puhul soodustasid vaadeldud faasiverbidega nullobjekti ka kahe tegevuse seostamine (43), koha-, aja-, viisimäärused, imperatiiv ja infinitiivitarindid, nt lõpetaks haiglas kipsijalgadega, soovib jätkata tegevspordis, alustas taas algkoosseisus, nii nagu meie omal ajal alustasime, äsja alustanud firma, tööpäeval alustan kell 7 ja lõpetan kell 20,jätka nagu enne, jätkake samas vaimus $\sim$ samal lainel $\sim$ valitud kursil, ta leidis julguse jätkata, tuleb alustada positiivsel noodil.

Muude sihitiseta kasutusjuhtude hulgas olid alustama $(n=7)$ ja lõpetama $(\mathrm{n}=27)$ puhul kaassõnastunud des-tarind (vt põhjalikumalt Erelt 2017e: 814), nt alustades lihtsatest, kohapeal õpitavatest puidutöödest ning lõpetades keerulisemate seadmete operaatoritega. Semantiliselt transitiivne kasutus esines alustama- ja lõpetama-verbide puhul vastavalt 9 ja 19 korral, nt alustatud kriminaalmenetlus, läbirääkimised on lõpetatud.

Verbi jooma puhul oli üks eesmärke vaadata, kas tõesti kasutatakse seda nullobjektiga peamiselt tähenduses 'alkoholi tarbima'. Nagu näitasid testimise tulemused, esines verb jooma selles tähenduses 129 nullobjektist 85 korral (66\%), nt jõi valget päeva nägemata, joome meie kõikide terviseks, mõttetus ajab jooma. Sageli soodustas nullobjekti hulga- või viisimäärus, nt noored joovad vähem, ära palju joo, eelistatakse juua mõõdutult. Otsetähenduses esines sihitiseta kasutust sööma-verbiga sarnastes mallides, nt tahan süüa ja juиa, öösel annan pojale tilaga tassist juua, on söönud ja joonud, söömata ja joomata kaua vastu ei pea, joo mitu korda päevas. 11 korral oli tegusõnavorm juua substantiivi rollis või kinnistunud 
väljendi osa, nt samuti on palju snäkki ja juua, juua täis inimene, ning 12 korral semantiliselt transitiivses kontekstis, nt kui hommikukohv joodud; maailmas enim joodud õlu.

Tegusõna nägema sihitisega kasutusjuhtude seas oli 500 korpuselauses üsnagi palju $(\mathrm{n}=119)$ analüütilisi tegusõnu (ette nägema, välja nägema, pealt nägema, ära nägema ja ka vaeva nägema) ning sageli oli sihitise rollis osalause $(\mathrm{n}=55)$, nt on tore näha, et ta õpib oma vigadest; arst aitas näha, mis on valesti. Sihitiseta esines nägema-verb järgmistes kontekstides: nagu ma näen nagu näha nagu näete vms, näed näete suhtlusvormelitena, nt aga näed, siiamaani elan; tähenduses 'kohtuma', nt näeme iga päev, pole ammu näinud, näeme (homme); modaalses otsetähenduses näevad nagu kotkad; tegi näo, et ta kaugele ei näe; vaatad, kuid ei näe. Lisaks leidus tulevikku väljendav ütlus elame, näeme ning üksikuid definiitseid nullobjekte, nagu Mina pole poes näinud _. Ühel korral oli muu kui sihitise rektsioon: püüab näha sügavamale. 19 korral oli tegemist semantiliselt transitiivse kasutusega, nagu tulemus on kohe näha, reisi jooksul nähtud sillad, filmi lõpp jääb jälle nägemata.

Siia rühma kuuluvad veel näiteks vaatama- ja kuulma-verbid, millel leidub leksikaliseerunud sihitiseta kasutusjuhte, nagu vaata või vaata ja imesta, vaatan peeglisse, kuulen, ning paralleelse, muu kui sihitise rektsiooniga verbid, nagu uskuma (usub seda $\sim$ sellesse), mõtlema (mõtleb seda $\sim$ sellele).

Eelmisest verbikategooriast eristab siia rühma kuuluvaid verbe see, et nende esinemiseks sihitiseta on üldjuhul vaja n-ö piiratumaid kontekste, nt tundub palju loomulikum öelda mulle meeldib nullist alustada kui lihtsalt mulle meeldib alustada (vrd ka ta jätkab praegu samas vaimus $\sim$ ta jätkab praegu liidrina ja ta jätkab praegu). Selle rühma verbidel on sagedasem ja loomulikum definiitne, sh leksikaalselt kinnistunud nullobjekt, eelmise rühma verbidel esineb lisaks definiitsetele nullobjektidele rohkesti indefiniitseid implitsiitseid objekte.

Mitmetähendusliku verbi puhul on mõnikord raske otsustada, kas verb kuuluks pigem siia või polüseemselt labiilsete verbide rühma. Lähtusin verbide jaotamisel sellest, et näiteks nägema-verbi puhul on kõik tähendused üksteisele üsna lähedased ning sihitiseta kasutus on pigem leksikaalselt kinnistunud nullobjekti sarnane. Kolmandasse rühma kuuluvate tegusõnade aitama ja lahutama puhul ei meenuta sihitiseta kasutusjuhud, nagu aitab küll ja nad lahutasid, nullobjekti juhtumeid. 


\subsection{Rangelt transitiivsed verbid}

Vaatlusaluses kategoorias on analüüsitud verbe moodustama,põhjustama, sisaldama, eeldama ja omama (vt tabel 6). On täheldatud, et nende verbide puhul on sihitis üldjuhul obligatoorne laiend ning sellesse rühma kuuluvad tegusõnad peaksid võimaldama üksnes definiitse objekti väljajättu ning sedagi väga piiratud kontekstides (Metslang 2017: 261).

Tabel 6. Verbide moodustama, põhjustama, sisaldama, eeldama ja omama esinemine nullsihitisega 500 korpuselauses

\begin{tabular}{|l|c|c|c|}
\hline Tegusõna & $\begin{array}{c}\text { Nullsihitisega kasutus- } \\
\text { juhtude arv: definiitne } \\
\text { nullobjekt (sh loomulik } \\
\text { nullobjekt) / indefiniitne } \\
\text { nullobjekt }\end{array}$ & $\begin{array}{c}\text { Muud } \\
\text { semantiliselt } \\
\text { transitiivsed } \\
\text { kasutus- } \\
\text { juhud }\end{array}$ & $\begin{array}{c}\text { Analüüsiks } \\
\text { mitte- } \\
\text { sobivate } \\
\text { lausete arv }\end{array}$ \\
\hline moodustama & $0 / 0$ & 0 & 3 \\
\hline põhjustama & $1(1) / 0$ & 91 & 5 \\
\hline sisaldama & $4(0) / 0$ & 0 & 4 \\
\hline eeldama & $8(0) / 0$ & 0 & 0 \\
\hline omama & $11(6) / 1$ & 1 & 12 \\
\hline
\end{tabular}

Verb moodustama esines materjalis mitmes üksteisega haakuvas tähenduses, tavaliselt substantiivse või kvantorisihitisega, nt publik moodustab saalis hingava ja köhiva neljanda seina, laps moodustab kahesõnalisi lauseid, vallavalitsus moodustab hoolekogu, eksport moodustab 17\% SKPst. Otseseid definiitseid vm nullobjekte 500 lause seast ei leitud, mis ei tähenda muidugi, et need pole võimalikud. Näiteks saab küsimusele „Kas sinu laps moodustab juba kahesõnalisi lauseid?“ vastata „Moodustab küll“. Samas leidus materjalis kvantumiosmaga sarnane näide, vrd nt (50) ja osmat See maksab 1900 eurot. Siin võib kas eeldada väljajäetud objekti (summa vms) või vaadelda sääraseid lauseid objekti ja osma piirijuhtumina.

(50) Soome keskmine pension moodustab 1900 eurot.

Analüüsitud lausete seas oli verbi põhjustama objekt samuti kas nimisõnavõi hulgasõnafraas, nt Naha kuivamist põhjustavad mitmed asjaolud; /--/ troopiliste metsade pindala vähenemine põhjustab 20\% maailma 
kasvuhoonegaaside emissioonist. Lisaotsingud näitasid, et sihitise funktsioonis võib olla ka osalause (51).

(51) Hambakivi põhjustas, et 2 eesmist alumist hammast ümbritsev ige taandus oluliselt.

Materjalis leidus üks loomuliku nullobjekti näide (/--/ on see põhjustanud _ja põhjustab jätkuvalt tõsist keskkonnamõju/--/). Lisaotsingutega leidus näiteid ka definiitse nullobjektiga (52).

(52) Ühtsuse puudumine ju põhjustabki_. [sõja]

91 korral oli tegu semantiliselt transitiivse kasutusega, nt rohkesti on kirjeldatud allergilisi reaktsioone, mis on põhjustatud mesilastest; elektrist põhjustatud õnnetuste arv Eestis on väga suur.

Nagu tegusõnad moodustama ja põhjustama esines verb sisaldama koos substantiivi- või kvantorifraasiga. Neljal korral oli võimalik pidada väljajäetud objektiks osastavas käändes sõna „järgmine“ (53). Võib eeldada, et see on muutumas kasutuseks, kus tegusõna sisaldama esineb nullobjektiga.

(53) Raamat sisaldab ka _ : ettevõtte riskikeskkond, riskide hindamine ja riskiturud /--/.

Tegusõna eeldama sihitis oli substantiivifraas (nt eeldab järjepidevust ja kannatlikkust, eeldatakse võõrkeelte oskust) või osalause (nt eeldan, et selline mõte võib tekkida).

Kaheksal korral esinenud nullsihitise puhul oli võimalik väljajäetud objekti asemele panna demonstratiivpronoomen see osastavas käändes, nagu näiteks väljendilaadsetes fraasides nagu_eeldada võis, (kiirem,) kui ma_eeldasin ning (54) puhul. Ühel korral esines objekti rollis proadverb nii (eeldan nii, sest ...). Säärased objektita esinemisjuhud on sarnased eelmise verbirühma regulaarseks muutunud nullobjekti kasutusjuhtudega (vt nt nägema) ning samasugust süntaktilist käitumist võimaldavad näiteks ka tegusõnad ütlema, arvama, ootama, tahtma ${ }^{8}$.

(54) /--/ kes, ma eeldan _, olid tegelikult tüdrukud riietatud poisteks.

8 Mainitud tegusõnade puhul on võimalik ka sihitiseta leksikaliseerunud kasutus, nagu nii öelda, ei oska öelda, ütleme, oota, tahan ja kõik. Arvama on ühtlasi ka ditransitiivne verb, kuna seda on võimalik kasutada kahe sihitisega, nt Ta arvas poisi koju minevat (Metslang 2017: 258-259). 
Verbi omama puhul oli sihitise rollis tavaliselt kas substantiivifraas (sageli kollokatiivse ühendina, nt omab tähtsust, omab ülevaadet) või kvantorifraas (nt omab 20\% Läti turust). Nullobjekt esines 12 korral. Nendest kuuel korral oli tegemist loomuliku nullobjektiga (nt omab_ja juhib 33 kaubanduskeskust), viiel korral esines definiitne nullsihitis (nt tuleb veel_omada [haridust], vähemalt tundub_omavat [mõju]) ja ühel korral indefiniitne nullsihitis (nüüdseks on oluline saavutada, jõuda, omandada, omada _, vallata). Ühel korral oli tud-tarind atribuudi funktsioonis (õemehe omatud auto).

Korpusepõhine analüüs näitas, et mõned rangelt transitiivsed verbid (nt omama) võivad põhimõtteliselt esineda indefiniitse nullobjektiga. Tegusõna eeldama võimaldab ka üsna regulaarseid sihitiseta konstruktsioone. Kahe mainitud verbi puhul esines samuti rohkem definiitset nullobjekti võrreldes verbidega moodustama, põhjustama ja sisaldama. Võib oletada, et eeldama ja omama puhul on alanud protsessid, mis viivad kunagi need verbid eelmisse verbikategooriasse. Hetkel jäävad nad pigem 6. rühma perifeeriasse.

Rangelt transitiivsete verbide hulka kuuluksid veel näiteks vähendama, suurendama, võimaldama, omandama, saavutama.

\section{Järeldused ja arutelu}

Kuue verbirühma tüüpiliste tegusõnade korpusepõhine testimine näitas, et eesti keeles võib eristada vähemalt kahte tüüpi intransitiivseid ja kolme tüüpi transitiivseid verbe. Nende vahele jäävad prototüüpselt ja polüseemselt labiilsed verbid, mille puhul võib olla ülekaalus kas intransitiivne või transitiivne kasutus. Kuut rühma võib vaadelda verbide transitiivsuse kontiinumina (vt joonis), kus iga kategooria on omakorda skalaarse loomuga. Nagu on kontiinumile iseloomulik, võivad mõned verbid olla mitme kategooria vahel, nt tantsima, laulma, harjutama, eeldama, omama. Teema edasisel uurimisel võivad ilmneda muudki vahepealsed juhtumid ning seeläbi saab jõuda täpsema ja detailsema jaotuseni.

Tundub loogiline, et üks tähtis kriteerium verbi transitiivsuse skaala kujunemisel on sihitisega esinemise sagedus. Tabelis 7 toodud arvandmed näitavad, et üldiselt intransitiivsete verbide ning prototüüpselt ja polüseemselt labiilsete verbide rühmas võib olla vägagi erinev objektiga 


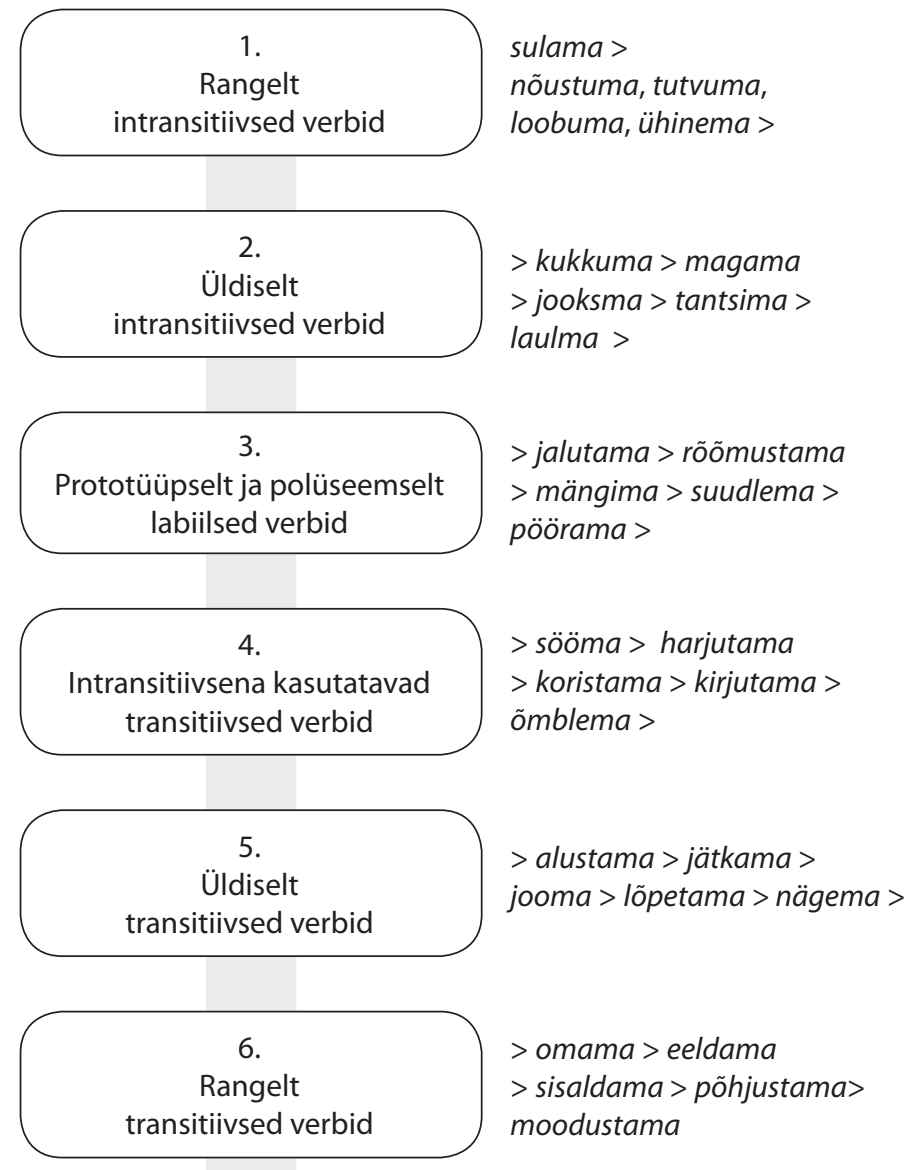

Joonis. Verbide transitiivsuse skaala eesti keeles

seonduvuse määr. Intransitiivsena kasutatavate ja üldiselt transitiivsete verbide rühmas on aga üsnagi sarnane sihitisega esinemise sagedus, mis näitab, et rühmade puhul oleks vaja rohkem andmeid, et saaks otsustada, kas tulevikus on mõistlik vaadelda neid ühe suure kategooria alltüüpidena või ikkagi kahe eraldi rühmana. 
Tabel 7. Verbirühmade sihitisega esinemise sagedus 500 korpuselauses

\begin{tabular}{|c|c|c|c|c|c|c|}
\hline Verbirühm & 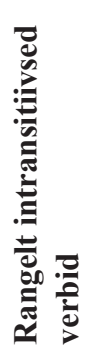 & 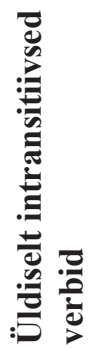 & 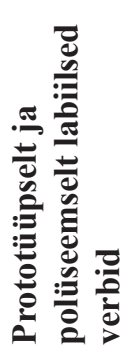 & 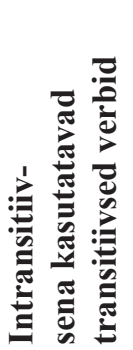 & 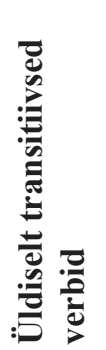 & 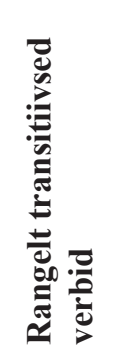 \\
\hline $\begin{array}{l}\text { Sihitisega } \\
\text { esinemine } \\
500 \text { korpuse- } \\
\text { lauses (\%) }\end{array}$ & 0 & $1-35$ & $3-83$ & $57-71$ & $57-87$ & $97-100$ \\
\hline
\end{tabular}

Tabel 8 võtab kokku artiklis analüüsitud verbitüüpide iseloomulikemad jooned: 1) rangelt intransitiivsed verbid: ei esine sihitisega, subjekt on kas mitteagentiivne või esineb agentiivse subjekti korral muu kui sihitise rektsioon; 2) üldiselt intransitiivsed verbid: agentiivse subjekti korral võivad esineda ebatüüpilise või sisaldussihitisega; 3) prototüüpselt ja polüseemselt labiilsed verbid: tihti on ülekaalus transitiivne või intransitiivne kasutus, ka prototüüpselt labiilsed verbid võivad olla polüseemsed; 4) intransitiivsena kasutatavad transitiivsed verbid: võimaldavad regulaarseid indefiniitseid nullobjekte, enamasti lause struktuurist või kontekstist tingituna; 5) üldiselt transitiivsed verbid: võimaldavad pigem definiitset kui indefiniitset nullobjekti, tihti esineb paralleelne, muu kui sihitise rektsioon, mis kas asendab sihitist või mida kasutatakse sellega koos; 6) rangelt transitiivsed verbid: üldjuhul ei võimalda objekti väljajättu.

On huvitav märkida, et Hopperi ja Thompsoni (1980) transitiivsuse kriteeriumitest kerkib analüüsitud materjalis esile eeskätt subjekti agentiivsus, kuid see mängib otsustavat rolli vaid üldiselt intransitiivsete verbide korral (agentiivne subjekt on kohustuslik tingimus sisaldussihitise ja ebatüüpilise objekti liitmiseks).

Korpusematerjali analüüs on kinnitanud, et nagu ka teiste keelte puhul võimaldavad mõned eesti keele transitiivsed verbid nullobjekti habituaalses ja korduvas olukorras ning kahe või enama tegevuse seostamisel. Sageli soodustavad nullobjekti eesti keeles: 1) infinitiivi- vm tarindid, nt tahan 
Tabel 8. Verbirühmade iseloomulikumate tunnuste esinemine

\begin{tabular}{|c|c|c|c|c|c|c|}
\hline $\begin{array}{l}\text { Verbirühm/ } \\
\text { tunnus }\end{array}$ & 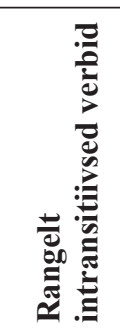 & 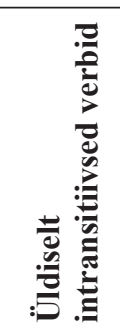 & 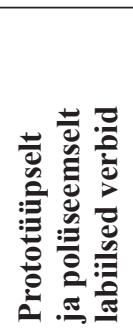 & 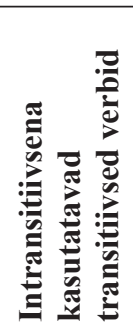 & 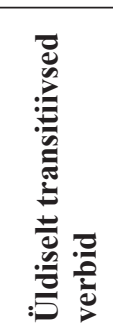 & 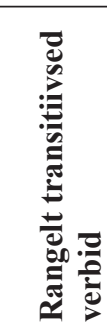 \\
\hline $\begin{array}{l}\text { Ebatüüpiline } \\
\text { objekt ja } \\
\text { sisaldussihitis }\end{array}$ & - & ++ & + & + & + & $-(?)$ \\
\hline $\begin{array}{l}\text { Definiitne } \\
\text { nullobjekt }\end{array}$ & - & + & + & + & ++ & + \\
\hline $\begin{array}{l}\text { Indefiniitne } \\
\text { nullobjekt }\end{array}$ & - & - & + & ++ & + & + \\
\hline $\begin{array}{l}\text { Muud } \\
\text { semantiliselt } \\
\text { transitiivsed } \\
\text { kasutusjuhud }\end{array}$ & - & + & + & + & + & + \\
\hline $\begin{array}{l}\text { Sihitist välis- } \\
\text { tav või asen- } \\
\text { dav määruslik } \\
\text { rektsioon }\end{array}$ & ++ & $-(?)$ & + & + & ++ & $-(?)$ \\
\hline Polüseemsus & $-(?)$ & + & ++ & + & + & + \\
\hline $\begin{array}{l}\text { Agentiivne } \\
\text { subjekt }\end{array}$ & + & ++ & + & + & + & + \\
\hline
\end{tabular}

- ei esine, - (?) materjalis ei esinenud, + esineb (sh vaid konkreetse verbi, tähenduse vms puhul), ++ iseloomulik joon

sü̈̈a, hakkas lõpetama, jätkata või mitte, käime söömas, pole saanud mängida, lapsed õpivad mängides; 2) kõrvallaused, nt kui me ei harjuta, siis me ei harju; 3) imperatiiv, nt söö kohe; 4) eri tüüpi määrused, nt sõime restoranis, laps joob juba tassist, mängib kontserdil, mängib ründajana, mängis tõesti hästi, mängivad koos 2001. aastast; 5) reduplikatiivne kordus, nt tuleb muidugi harjutada, harjutada ja harjutada; 6) otsekõne, nt „Nii see on “, lõpetas ta. Tulevikus oleks vajalik ja huvitav põhjalikumalt uurida sihitiseta kasutust spordivaldkonnas ja otsekõne korral. 
Intransitiivse-transitiivse kasutusega võib olla mitte ainult lihtverb, vaid ka analüütiline verb, nt katki kukkuma esineb nii intransitiivselt ('kukkus ja läks katki') kui ka transitiivselt ('kukkus nii, et miski läks katki'), jalutama ja ära jalutama on mõlemad A-labiilsed. Samuti on analüütiliste verbide puhul võimalik nullobjekt, nt maha magama on sage definiitse nullobjektiga (nt Magasin_jälle maha). Erinevusi lihtverbide ja analüütiliste tegusõnade transitiivsuse vahel peaks veel eraldi uurima.

On täheldatud, et sisaldussihitise ja nullobjekti kasutuse regulaarsus võib diakrooniliselt kas väheneda või suureneda (vt nt Lavidas 2013). Eesti keele puhul puuduvad veel kahjuks uurimused, mis näitavad, mis suunas on eesti keel liikumas. Selle artikli materjali põhjal võib oletada, et sisaldussihitise, ebatüüpilise ja nullobjekti kasutamine laieneb.

Verbi ambitransitiivse käitumise ja kasutusmallide suure variatiivsuse tingib sageli selle mitmetähenduslikkus (vt Luraghi 2004; Lorenzetti 2008). Nii on rangelt intransitiivsete ja rangelt transitiivsete verbide rühmas kõige väiksem tähenduste variatiivsus.

\section{Kokkuvõtteks}

Nagu paljude keele põhikategooriate puhul võib ka transitiivsust määratleda kui leksikaalgrammatilist kategooriat, mis on oma loomult skalaarne. Ühelt poolt on verbi kasutus transitiivne ehk sihiline siis, kui seda laiendab sihitis (süntaksi tasand), teiselt poolt sõltub see, kas verbi saab laiendada sihitis või mitte, verbi semantikast ja lause kontekstist (leksika tasand).

Artiklis on korpusematerjalil tõestatud, et eesti keeles võib eristada kahte intransitiivset verbiklassi (rangelt ja üldiselt intransitiivsed verbid), prototüüpselt ja polüseemselt labiilsete verbide rühma ning kolme transitiivset verbitüüpi (intransitiivsena kasutatavad, üldiselt ja rangelt transitiivsed verbid). Kõik rühmad koos moodustavad verbide transitiivsuse kontiinuumi ning eraldi vaadelduna võib põhimõtteliselt ka iga verbitüüp kujutada endast omaette kontiinuumi. Edasine uurimine võib pakkuda täpsema ja detailsema liigituse. 


\section{Kirjandus}

Dixon, R. M. W., Alexandra Y. Aikhenvald 2000. Introduction. - Changing Valency: Case Studies in Transitivity. Ed. by R. M. W. Dixon, Alexandra Y. Aikhenvald. Cambridge: Cambridge University Press, 9-29.

Erelt, Mati 2017a. Öeldis. - Eesti keele süntaks. Toim. Mati Erelt, Helle Metslang. (= Eesti keele varamu III.) Tartu: Tartu Ülikooli Kirjastus, 93-239.

Erelt, Mati 2017b. Öeldistäide. - Eesti keele süntaks. Toim. Mati Erelt, Helle Metslang. (= Eesti keele varamu III.) Tartu: Tartu Ülikooli Kirjastus, 278-288.

Erelt, Mati 2017c. Ellips. - Eesti keele süntaks. Toim. Mati Erelt, Helle Metslang. (= Eesti keele varamu III.) Tartu: Tartu Ülikooli Kirjastus, 590-602.

Erelt, Mati 2017d. Rinnastus. - Eesti keele süntaks. Toim. Mati Erelt, Helle Metslang. (= Eesti keele varamu III.) Tartu: Tartu Ülikooli Kirjastus, 603-646.

Erelt, Mati 2017e. Sekundaartarindiga laused. - Eesti keele süntaks. Toim. Mati Erelt, Helle Metslang. (= Eesti keele varamu III.) Tartu: Tartu Ülikooli Kirjastus, 756-840.

Goldberg, Adele E. 2001. Patient arguments of causative verbs can be omitted: The role of information structure in argument distribution. - Language Sciences 23 (4-5), 503-524. https://doi.org/10.1016/S03880001(00)00034-6

Hopper, Paul J., Sandra A. Thompson 1980. Transitivity in grammar and discourse. - Language 62 (2), 251-299. https://doi.org/10.2307/413757

Horita, Yuko 1996. English cognate object constructions and their transitivity. English Linguistics 13, 221-247. https://doi.org/10.9793/elsj1984.13.221

Keenan, Edward L., Matthew S. Dryer 2007. Passive in the world's languages. - Language Typology and Syntactic Description. Vol. I: Clause Structure. Ed. by Timothy Shopen. Cambridge: Cambridge University Press, 325-361. https://doi.org/10.1017/CBO9780511619427.006

Kehayov, Petar, Virve-Anneli Vihman 2014. The lure of lability: A synchronic and diachronic investigation of the labile pattern in Estonian. - Linguistics 52 (4), 1061-1105. https://doi.org/10.1515/ling-2014-0016

Kilgarriff, Adam, Vít Baisa, Jan Bušta, Miloš Jakubíček, Vojtěch Kovář, Jan Michelfeit, Pavel Rychly, Vít Suchomel 2014. The Sketch Engine: Ten years on. - Lexicography 1, 7-36. https://doi.org/10.1007/s40607014-0009-9

Kitahara, Ken-ichi 2010. English Cognate Object Constructions and Related Phenomena: A Lexical-Constructional Approach. PhD Dissertation. University of Tsukuba.

Kont, Karl 1963. Käändsõnaline objekt läänemeresoome keeltes. (= Keele ja Kirjanduse Instituudi uurimused IX.) Tallinn. 
Kulikov, 1999. May he prosper in offspring and wealth: A few jubilee remarks on the typology of labile verbs and Sanskrit púşyati 'prospers; makes prosper'. - Typology and Linguistic Theory: From Description to Explanation. For the 60th birthday of Aleksandr E. Kibrik. Ed. by Ekaterina V. Rakhilina, Yakov G. Testelets. Moscow: Languages of Russian Culture, 224-244.

Lavidas, Nikolaos 2013. Null and cognate objects and changes in (in)transitivity: Evidence from the history of English. - Acta Linguistica Hungarica 60 (1), 69-106.

Lehrer, Adrienne 1970. Verbs and deletable objects. - Lingua 25, 227-253. https://doi.org/10.1016/0024-3841(70)90036-7

Letuchiy 2006a $=$ Александр Б. Летучий 2006а. Типология лабильных глаголов: Семантические и морфосинтаксические аспекты. Диссертация. Москва.

Letuchiy 2006b = Александр Б. Летучий 2006b. Лабильность в русском языке: случайность или закономерность? - Computational Linguistics and Intellectual Technologies. International Conference „Dialogue 2006“ Proceedings, 343-347.

Letuchiy 2013 = Александр Б. Летучий 2013. Типология лабильных глаголов. Москва: Языки славянской культуры.

Lorenzetti, Maria I. 2008. The null instantiation of objects as a polysemy-trigger. A study on the English verb see. - Lexis. Journal of English Lexicology 1, 59-83. https://doi.org/10.4000/lexis.769

Luraghi, Silvia 2004. Null objects in Latin and Greek and the relevance of linguistic typology for language reconstruction. - Proceedings of the Fifteenth Annual UCLA Indo-European Conference. Ed. by Karlene Jones-Bley, Martin E. Huld, Angela D. Volpe, Mirriam R. Dexter. (= Journal of Indo-European Monograph Series 49.) Washington: Institute for the Study of Man, 235-256.

McMillion, Alan 2006. Labile Verbs in English: Their Meaning, Behavior and Structure. PhD Dissertation. Stockholm: Stockholm University.

Metslang, Helena 2008. Sihitisesarnased määrused: kui sarnased? - Lähivõrdlusi. Lähivertailuja 18, 108-143. http://dx.doi.org/10.5128/LV18.06

Metslang, Helle 2017. Sihitis. - Eesti keele süntaks. Toim. Mati Erelt, Helle Metslang. (= Eesti keele varamu III.) Tartu: Tartu Ülikooli Kirjastus, 258-277.

Metslang, Helle, Külli Habicht, Tiit Hennoste, Anni Jürine, Kirsi Laanesoo, David Ogren 2017. Artikkel onnesoovidega. Komitatiivi funktsioonidest eri aegade ja registrite eesti kirjakeeles. - Eesti ja soome-ugri keeleteaduse ajakiri. The Journal of Estonian and Finno-Ugric Linguistics 8 (1), 149-178. https://doi.org/10.12697/jeful.2017.8.1.09 
Neshcheret, Nataliia 2016. Passive Construction with Intransitiive Verbs: Typology and Distribution. M.A Thesis. Kiel: University of Kiel.

Nass, Åshild 2007. Prototypical Transitivity. (= Typological Studies in Language 72.) Amsterdam: John Benjamins Publishing Company. https:// doi.org/10.1075/tsl.72

Næess, Åshild 2011. The grammar of eating and drinking verbs. - Language and Linguistic Compass 5 (6), 413-423. https://doi.org/10.1111/j.1749818X.2011.00279.X

Onozuka, Hiromi 2007. Remarks on causative verbs and object deletion in English. - Language Sciences 29 (4), 538-553. https://doi.org/10.1016/j. langsci.2006.01.002

Rätsep, Huno 1978. Eesti keele lihtlausete tüübid. Tallinn: Valgus.

Tamm, Anne 2012. Scalar Verb Classes: Scalarity, Thematic Roles, and Arguments in the Estonian Aspectual Lexicon. Firenze: Firenze University Press. https://doi. org/10.36253/978-88-6655-055-6

Torn, Reeli 2002. The status of the passive in English and Estonian. - RCEAL Working Papers in English and Applied Linguistics 7. Ed. by H. Hendrik. Cambridge: Research Centre for English and Applied Linguistics, 81-106.

Veismann, Ann, Mati Erelt, Helle Metslang 2017. Määrus. - Eesti keele süntaks. Toim. Mati Erelt, Helle Metslang. (= Eesti keele varamu III.) Tartu: Tartu Ülikooli Kirjastus, 300-375.

Velasco, Daniel G., Carmen P. Muñoz 2002. Understood objects in functional grammar. - Working Papers in Functional Grammar 76. https://home. hum.uva.nl/fg/working_papers/wpfg76.pdf

\section{Võrgumaterjalid}

ENC19 = Jelena Kallas, Kristina Koppel 2020. Eesti keele ühendkorpus 2019 [Estonian National Corpus 2019]. Center of Estonian Language Resources. https://doi.org/10.15155/3-00-0000-0000-0000-08489L (01.02.2021)

Kallas, Jelena, Mai Tiits, Maria Tuulik, Kristina Koppel, Madis Jürviste 2015. Eesti keele põhisõnavara sõnastik (veebiversioon). https://doi. org/10.15155/3-00-0000-0000-0000-05925L 


\title{
The verbal transitivity continuum in Estonian
}

\author{
NATALIA VAISS
}

The article summarizes the previous findings of research on transitivity in Estonian verbs and offers analysis based on the 2019 Estonian National Corpus to prove a six-stage transitivity continuum in Estonian. The following verb groups are distinguished: 1) strictly intransitive verbs, 2) generally intransitive verbs, 3) prototypical labile (ambitransitive) and polysemic labile verbs, 4) transitive verbs used as intransitives with the focus on activity, 5) generally transitive verbs, and 6) strictly transitive verbs. For the aforementioned groups, five representative verbs have been selected, whose syntactic-semantic features have been controlled through the corpus materials by using Sketch Engine software functions Word Sketch, Concordance, and Shuffle. For each verb, the first 500 results have been analysed. The further research needs are also discussed.

Keywords: verbal syntax, agreement, differential object marking, polysemy, corpus linguistics

Natalia Vaiss

Eesti Keele Instituut

Humanitaarteaduste instituut

Tallinna Ülikool

Narva mnt 25

10120 Tallinn

navaiss@tlu.ee 